Document downloaded from:

http://hdl.handle.net/10251/171121

This paper must be cited as:

Juárez, JD.; Marco-Jiménez, F.; Talaván, AM.; García-Domínguez, X.; Viudes-De-Castro, MP.; Lavara, R.; Vicente Antón, JS. (2020). Evaluation by re-derivation of a paternal line after 18 generations on seminal traits, proteome and fertility. Livestock Science. 232:1-13. https://doi.org/10.1016/j.livsci.2019.103894

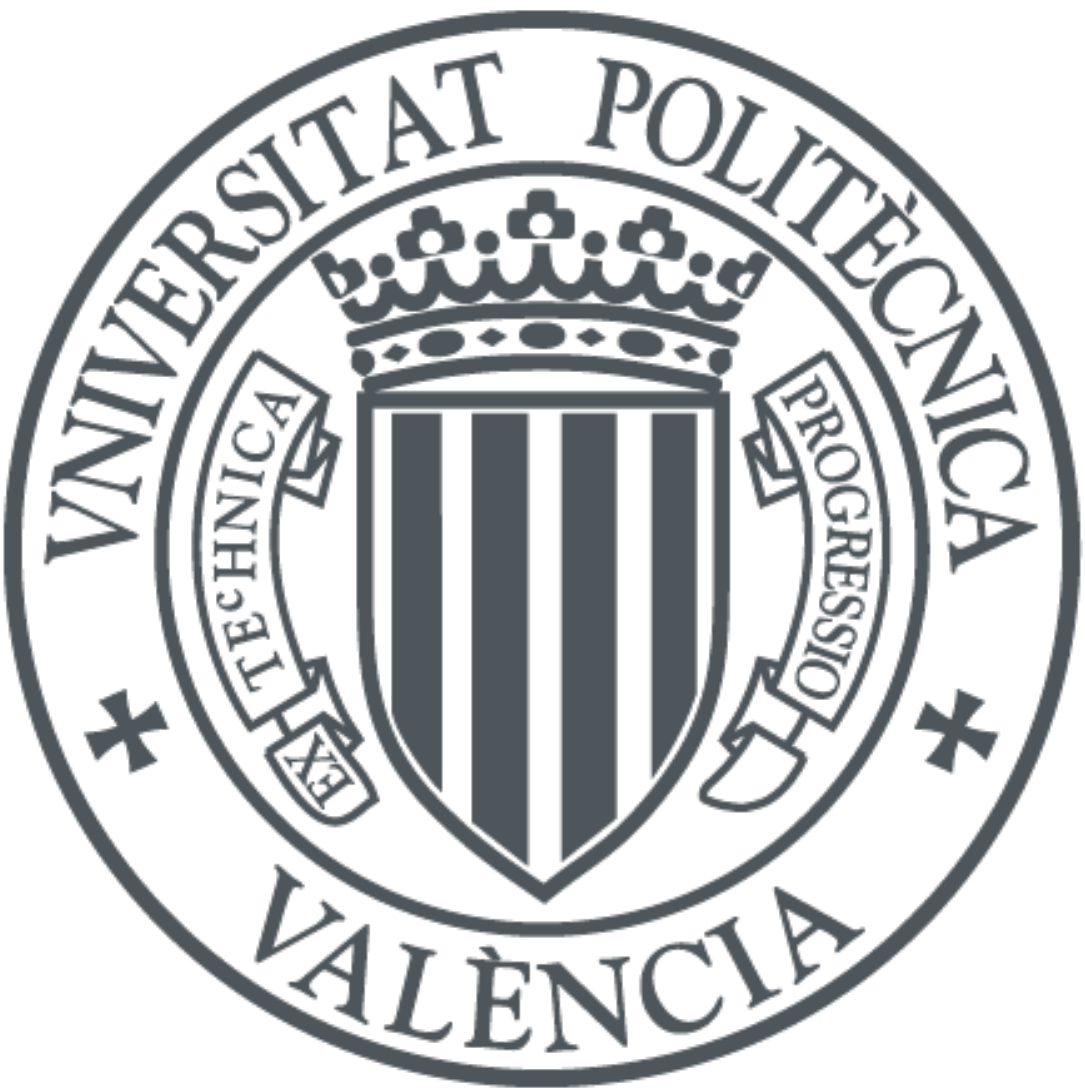

The final publication is available at

https://doi.org/10.1016/j.livsci.2019.103894

Copyright Elsevier

Additional Information 


\title{
Evaluation by re-derivation of a paternal line after 18 generations on seminal traits,
} proteome and fertility

\author{
J.D. Juarez ${ }^{1}$, F. Marco-Jiménez ${ }^{2}$, A.M. Talaván², X. García-Domínguez ${ }^{2}$, M.P. Viudes-de- \\ Castro $^{3}$, R. Lavara ${ }^{2}$, J.S. Vicente ${ }^{2}$ \\ ${ }^{1}$ Facultad de Zootecnia, Universidad Nacional Agraria de la Selva, 64 Tingo María, Perú \\ ${ }^{2}$ Instituto de Ciencia y Tecnología Animal, Universitat Politècnica de València, 46022 \\ Valencia, Spain \\ ${ }^{3}$ Centro de Investigación y Tecnología Animal, Instituto Valenciano de Investigaciones \\ Agrarias, 12100 Segorbe (Castellón), Spain.
}

\section{Abstract}

Males from a paternal line selected for growth traits were used to produce semen doses at insemination centres and farms in a breeding scheme for rabbit meat production. The aim of this study was to assess whether a programme of selection by daily gain in fattening period changed the seminal traits, plasma and sperm proteome and the fertility of semen when used in artificial insemination. Thirty-nine males from a paternal line were obtained by re-derivation from vitrified embryos with a difference of 18 generations (G21V and G39V). Sperm production parameters, morphological traits, sperm motility parameters and viability were evaluated from ejaculates. Seminal plasma and sperm proteome of three pool ejaculates from 10 mature males of each group were analysed and semen doses were used to inseminate 311 females. Only the percentage of abnormal sperm showed significant differences, with G21V presenting fewer abnormal sperm than G39V (10.5 \pm 2.63 vs $23.8 \pm 1.98)$. The discriminant analysis (DA-PLS) showed a clear effect of the generation for plasma and sperm proteome. In seminal plasma, 643 proteins were reported and 64 proteins were differentially expressed, of which 56 were overexpressed in G39V (87.5\%). Sperm proteome reported 1360 proteins with 132 differentially abundant proteins. Of the total, 89 proteins were overexpressed in G39V (67.4\%). From the 64 and 132 differentially abundant proteins of plasma and sperm, 19 and 26 had a FC>1.5, 12 and 13 of them belonging to the Oryctolagus cuniculus taxonomy, 
respectively. Despite observing differences in important proteins related to capacitation, sperm motility or immunoprotection and consequently to the fertilization process (TMPRSS2, Serpin family, Fam71f1, ATPase H+ transporting accessory protein 2, carbonic anhydrase 2, UDPglucose glycoprotein glucosyltransferase 2), no differences in fertility and prolificacy were detected when commercial seminal doses were used for insemination from both male groups. However, overabundance of KIAA1324 protein can be related to the increase in abnormal sperm after selection by growth rate.

Keywords: Sperm, Proteome, Growth rate, Selection, Rabbit.

\section{Introduction}

Breeding schemes for meat production in rabbits involved a three-way cross of specialized lines in which paternal line males inseminate maternal crossbred females. Paternal line or terminal sires are selected for growth traits (Rochambeau et al., 1989, Estany et al. 1992, Lukefahr et al., 1996; Larzul et al., 2005), as the males are used for the production of seminal doses at insemination centres and farms. Therefore, males from growth lines must produce semen in sufficient quantity and quality to meet the demand for insemination. Nevertheless, several studies have shown that selection for growth has effects on reproductive performance in both females and males (Bunger et al., 2005). In rabbits, negative effects have been observed in ovulation induction, prenatal survival and genetic correlation to fertility (Vicente et al., 2012; Piles et al., 2012) and ejaculate traits such as mass motility, volume, abnormal sperm rate or head sperm morphometry (Brun et al., 2006; Lavara et al., 2012 and 2013).

Many factors influence the production and quality of rabbit semen, such as collection frequency (Nizza et al., 2003), environment (season or photoperiod, Marai et al., 2002, Pascual et al., 2004, Roca et al., 2005; Theau-Clément et al., 2015, Sabés-Alsina et al., 2015), nutrition 
(Pascual et al., 2004 and 2016) and genetic line (Vicente et al., 2000, Brun et al., 2002 and 2006; García-Tomás et al., 2006a, Piles et al., 2013). Genetic parameters for ejaculate traits show a moderate repeatability and low to moderate heritability in most of them (García-Tomás et al., 2006b; Lavara et al., 2011, Tussell et al., 2012; Brun et al., 2016). Tussell et al. (2012) found a moderate heritability for concentration, volume and sperm production in a rabbit line selected by daily gain and, a low or uncorrelated genetic response between daily gain and these ejaculate traits, as consequence non detrimental effect is expected on sperm production. In this sense, Lavara et al. (2012 and 2013) observed no effects on sperm production but showed moderate negative correlations between daily weight gain and normal acrosome status, sperm motility and the morphometry of sperm heads, suggesting that genes that favour daily weight gain slightly decrease normal acrosome status and increase abnormal sperm forms.

The production of semen doses requires the estimation of different parameters of seminal quality, among which motility and morphology are the most widely used. It is accepted that conventional seminal parameters provide a low correlation with male fertility. Due to these limitations, efforts must be made to understand and identify sperm biomarkers at molecular level in seminal plasma and sperm. In this sense, some works have tried to better understand the role of seminal plasma. Castellini et al. (2000) observed that seminal plasma enhanced both the resistance of rabbit spermatozoa to in vitro storage and their motility characteristics. Seminal plasma contains, in the others components, several proteinases involved in physiological events, ranging from immunosuppressive activity to the enhancement of sperm cell motility or fertility. Viudes de Castro et al. (2014 and 2015) reported differences between genetic lines and showed that high levels of aminopeptidase activity of rabbit seminal plasma was related with abnormal sperm rates and lower percentages of normal apical ridge, however, no effects on fertility was observed. In mouse, deficient aminopeptidase activity was associated with infertility, lack copulatory behavior and impaired spermatogenesis (Osada et al., 2001). 
Several authors have observed that some seminal parameters significantly influenced kindling rate in rabbit, such as acrosome integrity and chromatin structure (Courtens et al., 1994), mass motility and total motile sperm per dose (Brun et al. 2002 and Hagen et al., 2002) and the percentage of abnormal sperm (Lavara et al., 2005).

Most of the previous studies have been focused on the effects of selection on the seminal and sperm parameters, but little attention has been paid to the protein seminal plasma or sperm composition and whether these changes could affect the fertility of seminal doses obtained from the paternal males. In this context, the study of the proteome is of great interest, as plasma and sperm proteins play a key role in the maintenance of sperm morphology, motility patterns, acrosome formation and reaction, capacitation and fertilization. Recently, Casares-Crespo et al. (2018 and 2019) analysed the effect of the genetic origin of two rabbit lines (maternal and paternal) and season on the seminal and sperm proteome. They identified 402 and 487 proteins in seminal plasma and spermatozoa respectively, providing evidence that genotype had a huge impact on protein abundance in rabbit ejaculates. Whether these different proteome patterns justify cryotolerance and fertility differences observed previously in these lines has yet to be resolved (Mocé et al., 2003). Finally, Bezerra et al. (2019) identified 137 different seminal plasma proteins and identified potential associations between the major seminal plasma proteome and some semen traits in rabbits. Among other findings, they noted that sperm motility had a positive association with beta-nerve growth factor and cysteine-rich secretory protein 1-like and a negative one with galectin-1, that intact sperm membrane was related to seminal plasma protein FAM115 complex and tropomyosin or that morphologically normal sperm was positively linked to carcinoembryonic antigen-related cell adhesion molecule 6-like and down regulated by seminal plasma isocitrate dehydrogenase.

The aim of this study was to evaluate whether a selection programme by daily gain in fattening period affects ejaculate traits, seminal plasma and sperm proteome and semen fertility. 


\section{Materials and methods}

All chemicals, unless otherwise stated, were reagent-grade and purchased from SigmaAldrich Química S.A. (Alcobendas, Madrid, Spain). All the experimental procedures used in this study were performed in accordance with the principles of animal care published by Spanish Royal Decree 53/2013 (BOE 2013) and the Directive 2010/63/EU EEC for animal experiments and reviewed and approved by the Ethics and Animal Welfare Committee of the Universitat Politècnica de València (Research code, 2015/VSC/PEA/00061).

\subsection{Animals}

A total of 39 males from genetic line $\mathrm{R}$ from the Universitat Politècnica de València were used. Line $\mathrm{R}$ is a paternal line selected over 36 generations for daily gain from 28 to 63 days of age (Estany et al. 1992). Selection is based on phenotypic values of daily gain and is conducted in non-overlapping generations. Environmental conditions were maintained using a control system for light (16:8 light/dark photoperiod), with free access to water and commercial pelleted diets (minimum of $15 \mathrm{~g}$ of crude protein per $\mathrm{kg}$ of dry matter, $15 \mathrm{~g}$ of crude fibre per $\mathrm{kg}$ of DM, and 10.2 MJ of digestible energy per kg of dry matter).

A total of 311 commercial crossbreed females were used to perform the fertility and prolificacy study. Females were kept in similar environmental conditions.

\subsection{Experimental design}

Two populations of $\mathrm{R}$ line males were used for this experiment. Both were obtained from embryos vitrified in 2015. The $18^{\text {th }}$ generation was re-derived from vitrified embryos stored in $2000(\mathrm{G} 19 \mathrm{~V})$ and a sample of embryos from the current generation $\left(36^{\text {th }}\right)$ was vitrified and transferred at the same time to establish the G37V population. The reconstitution of respective generations was successfully done with 8 families from G19V and 9 from G37V of different male origin (Figure 1). 
After two generations without selection, to avoid possible effects of cryopreservation and transfer procedures on growth and reproductive performance, males from different generations (G21V and G39V) were trained and evaluated.

\subsection{Semen collection}

At 5 months of age, males started a four-weeks training period with artificial vaginas; one ejaculate was collected per male weekly. Semen collection was performed using a receptive doe and the response of the males to the collection procedure was recorded during the training period until the beginning of the experimental period. At the $6^{\text {th }}$ month of age males were subjected to experimental evaluation. Collections were performed on the same day for 10 weeks; one ejaculate was collected per male and per week to assess the seminal parameters. Only ejaculates exhibiting a white colour were used in the experiment; if the first ejaculate was not available (with urine, sediment or cell debris), a second one was collected 20 minutes later. Gel was removed if present.

Males were weighted weekly during experimental period.

\subsection{Evaluation of ejaculates}

\subsubsection{Ejaculate quantity and sperm production}

The ejaculate volume was measured in a graduated tube. To determine sperm concentration, aliquots of each ejaculate were diluted 1:50 with $0.25 \%$ of glutaraldehyde solution in Dulbecco's phosphate buffered saline, using a Thoma-Zeiss counting cell chamber (Marienfield, Germany). Total sperm per ejaculate (TSE) was calculated using volume and concentration from each ejaculate.

\subsubsection{Ejaculate quality}

\subsubsection{Sperm morphological traits}

To measure acrosome integrity percentage (normal apical ridge) and percentage of abnormal forms (abnormal head and tails), a sample of spermatozoa from each ejaculate was 
fixed with a solution of glutaraldehyde $(0.25 \%$ in Dulbecco's phosphate buffered saline) and the samples were examined under a phase contrast optical microscope at $x 400$ magnification.

\subsubsection{Sperm motility parameters}

Ejaculate samples were diluted in a Tris-citrate-glucose extender (TCG: $250 \mathrm{mM}$ trishydroxymethylaminomethane, $83 \mathrm{mM}$ citric acid, 50mM glucose, $\mathrm{pH} 6.8 \pm 7.0,300 \mathrm{mOsm} / \mathrm{kg}^{-1}$ ) to obtain a concentration of $30 \times 10^{6} \mathrm{sperm} / \mathrm{mL}$. An aliquot from each sample was then adjusted to $7.5 \times 10^{6} \mathrm{sperm} / \mathrm{mL}$ with TCG extender supplemented with $2 \mathrm{~g} / \mathrm{L}$ BSA, then $10 \mu \mathrm{l}$ were placed in a Makler counting chamber pre-warmed at $37^{\circ} \mathrm{C}$ on a thermal plate and evaluated in an Integrated Semen Analysis System v. 1.0.17 (ISAS; Projectes i Serveis R+D S.L.). The system was set to record images at 30 frames/s. Motility was assessed at $37^{\circ} \mathrm{C}$ at $200 \mathrm{X}$ using a negative phase contrast microscope. For each sample, six microscopic fields were analysed and a minimum of 400 sperm evaluated. The curvilinear velocity (VCL, the average velocity measured over the actual point to point track followed by the cell), straight-line velocity (VSL, the average velocity measured in a straight line from the beginning to the end of the track), average path velocity (VAP, the average velocity of the smoothed cell path), linearity index (LIN; the average value of the ratio VSL/VCL), straightness (STR, the ratio between VSL and VAP), wobble $(\mathrm{WOB}=(\mathrm{VAP} / \mathrm{VCL}) \times 100$, a measure of the oscillation of the actual trajectory about its spatial average path), amplitude of lateral head displacement (ALH, the mean width of the head oscillation as the sperm cells swim) and beat cross-frequency (BCF, the frequency of sperm head crossing the average path in either direction) were evaluated. All captures were saved and analysed later. Before field analysis, we proceeded to identify each sperm trajectory to eliminate debris (false captures) and reduce the risk of confusing trajectories.

\subsubsection{Viability and HOST analysis}

The percentage of viable sperm was determined using a dual fluorescent staining with SYBR-14/PI according to Viudes de Castro et al. (2014). A minimum of 100 sperm cells were 
counted per ejaculate, and only the percentages of live sperm were considered in the results (SYBR-14-positive and PI-negative). All dilutions were performed at $22^{\circ} \mathrm{C}$.

A hypo-osmotic swelling test (HOST) was used to evaluate the functional integrity of the sperm membrane (Jeyendran et al., 1984). Semen was diluted 1:20 in a HOST solution of $75 \mathrm{mOsm}$ at $25-30^{\circ} \mathrm{C}$ for $15 \mathrm{~min}$. A minimum of 100 sperm cells were evaluated and HOST was calculated as the percentage of spermatozoa with swollen coiled tails/total spermatozoa.

\subsection{Plasma and Sperm protein extraction samples}

Ejaculates from 20 mature males (10 for each experimental group "G21V and G39V”) were collected and pooled. Six pooled ejaculates (three for each group of males) were obtained in three different weeks and used for insemination. Before preparing the sperm doses, a sample of $500 \mu 1$ from ejaculate pools was centrifuged at $7,400 \mathrm{x}$ for $10 \mathrm{~min}$ at $22^{\circ} \mathrm{C}$. The supernatants (seminal plasma) were collected, supplemented with a $1 \% \mathrm{v} / \mathrm{v}$ protease inhibitor cocktail (P2714, Sigma) and stored at $-80^{\circ} \mathrm{C}$ until use. The resulting pellets were washed twice by centrifugation at $900 \mathrm{xg}$ for $10 \mathrm{~min}$ in PBS. Sperm proteins were extracted according to the Casares-Crespo et al. (2019) protocol. Briefly, sperm pellets were resuspended in 1\% SDS (w/v) in TCG (Tris-citrate-glucose supplemented with a $1 \% \mathrm{v} / \mathrm{v}$ protease inhibitor cocktail, P2714) and sonicated on ice 6 times for $5 \mathrm{~s}$ at 30\% amplitude using an Ultrasonic Lab Homogenizer UP $100 \mathrm{H}$ (Hielscher Ultrasonics GmbH). After sonication, the solution was kept in ice for 15 min and centrifuged for $10 \mathrm{~min}$ at $15,000 \mathrm{~g}$ at $4^{\circ} \mathrm{C}$. Protein lysates were stored at $-80^{\circ} \mathrm{C}$ until use.

\subsection{Proteomic relative quantification analysis: SWATH (DIA) MSMS analysis}

The proteomic analyses were performed in SCSIE of the Universitat de València (PRB3-ISCIII ProteoRed Proteomics Platform).

Initial protein concentration from seminal plasma was measured by Nanodrop (Thermo Scientific) using diluted (1 to 10) samples in ultrapure water and the concentration of sperm protein sample by Machery Nagel quantitation kit (Ref. 740967.50), following the 
manufacturer's protocol. A pool of seminal plasma and another with sperm samples were prepared with $50 \mu \mathrm{g}$ of protein and resolved in 1D PAGE gel.

\subsubsection{Spectral libraries building}

In gel protein digestion: 5 gel slides in each gel were digested with sequencing grade trypsin (Promega) as described by Shevchenko et al. (1996). Gel slides were digested using 200 and $400 \mathrm{ng}$ of trypsin and digestion was set to $37^{\circ} \mathrm{C}$ (on seminal and sperm slides, respectively). The trypsin digestion was stopped with $10 \%$ trifluoroacetic acid (TFA) and the supernatant (SN) was removed, then the library gel slides were dehydrated with pure acetonitrile (ACN). The new peptide solutions were combined with the corresponding SN. The peptide mixtures were dried in a speed vacuum (ISS 110 SpeedVac System, Thermo Savant, ThermoScientific, Langenselbold, Germany) and resuspended in $2 \%$ ACN; $0.1 \%$ TFA. The volumes were adjusted according to the intensity of the staining.

LCMSMS data dependent acquisition (DDA) analysis: $5 \mu 1$ of the digested fragments were loaded into a trap column (NanoLC Column, $3 \mu \mathrm{C} 18-\mathrm{CL}, 75 \mu \mathrm{x} 15 \mathrm{~cm}$; Eksigent) and desalted with $0.1 \% \mathrm{TFA}$ at $3 \mu \mathrm{l} / \mathrm{min}$ for $5 \mathrm{~min}$. The peptides were loaded into an analytical column (LC Column, $3 \mu$ C18-CL, $75 \mu$ x 12cm, Nikkyo Technos, Tokyo, Japan) equilibrated in $5 \%$ ACN $0.1 \%$ formic acid (FA). Peptide elution was carried out with a linear gradient of 5 to $35 \%$ of solvent $\mathrm{B}$ for $60 \mathrm{~min}(\mathrm{~A}: 0.1 \% \mathrm{FA}$ in water; $\mathrm{B}$ : $0.1 \% \mathrm{FA}$ in $\mathrm{ACN})$ at a flow rate of 300nL/min. Peptides were analysed in a nanoESI qTOF mass spectrometer (5600 TripleTOF, ABSCIEX).

The tripleTOF was operated in information-dependent acquisition mode, in which a 250-ms TOF MS scan from 350-1250 m/z, was performed, followed by 150 -ms product ion scans from $350-1500 \mathrm{~m} / \mathrm{z}$ on the 25 most intense $2-5$ charged ions. The rolling collision energies equations were set for all ions as for $2+$ ions, according to the following equations: $|\mathrm{CE}|=($ slope $) \mathrm{x}(\mathrm{m} / \mathrm{z})+($ intercept $)$. 


\subsubsection{ProteinPilot v5.0. search engine (Sciex).}

ProteinPilot default parameters were used to generate a peak list directly from 5600 TripleTof wiff files. The Paragon algorithm (Shilov et al., 2007) of ProteinPilot was used to search the UniprotMammalia database (03.2018) with the following parameters: trypsin specificity, cys-alkylation, without taxonomy restriction, and the search effort set to through and False Discovery Rate (FDR) correction for proteins. The protein grouping was done by Pro group algorithm. Here, the formation of protein groups is guided entirely by observed peptides only, which originate from the experimentally acquired spectra. Because of this, the grouping can be considered to be guided by use of spectra.

\subsubsection{Swath analysis of samples}

Protein digestion of seminal plasma samples: $25 \mu \mathrm{g}$ of every sample were reduced by 2 $\mathrm{mM}$ dithiothreitol (DTT; $\mathrm{Vf}=25 \mu \mathrm{L}$ ) for 20 minutes at $60^{\circ} \mathrm{C}$. The thiol groups were alkylated by $5.5 \mathrm{mM}$ Iodoacetamide (IAM, $\mathrm{Vf}=30 \mu \mathrm{L}$ ) for 30 minutes at room temperature in the dark. The excess of IAM was quenched with $10 \mathrm{mM}$ DTT $(\mathrm{Vf}=60 \mu \mathrm{L})$ at $37^{\circ} \mathrm{C}$ for 1 hour. For protein digestion, $500 \mathrm{ng}$ of trypsin were added $(\mathrm{Vf}=65 \mu \mathrm{L})$ and digestion was left overnight. All the reagents were prepared in $50 \mathrm{mM}$ Ammonium bicarbonate solution. The protein digestion was stopped with $5 \mu \mathrm{L}$ of $10 \%$ Trifluoro-Acetic acid (TFA) in water. The final mixture volume was $70 \mu \mathrm{L}$. Samples were concentrated by rotatory evaporator to $25 \mu \mathrm{L}$. The individual SWATH injections were randomized in blocs.

Protein digestion sperm samples: the protein gel mixtures were digested as described by Shevchenko et al. (1996), using $500 \mathrm{ng}$ of trypsin for each sample and digestion was set to 37 ${ }^{\circ} \mathrm{C}$. The trypsin digestion was stopped with $10 \% \mathrm{TFA}$ and the $\mathrm{SN}$ was removed, then the library gel slides were dehydrated with pure ACN. The new peptide solutions were combined with the corresponding SN. The peptide mixtures were dried in a speed vacuum and resuspended in $2 \%$ ACN; $0.1 \%$ TFA. The volume was adjusted to a final concentration of $0.5 \mu \mathrm{g} / \mu \mathrm{L}$. 
SWATH LCMSMS analysis: $5 \mu$ l of every sample were chromatographically resolved as in 2.6.1 but with a 120-minute gradient. The tripleTOF was operated in Swath mode, in which a 0.050 -s TOF MS scan from $350-1250 \mathrm{~m} / \mathrm{z}$ was performed, followed by 0.080 -s product ion scans from $350-1250 \mathrm{~m} / \mathrm{z}$ on the 32 defined windows ( $3.05 \mathrm{sec} / \mathrm{cycle})$. The Swath windows used were: $15 \mathrm{Da}$ window widths from 450 to $1000 \mathrm{Da}, 37$ windows.

Protein quantification: the wiff files obtained from the Swath experiment were analysed by Peak View 2.1. The processing settings used for the peptide selection were: a maximum number of peptides per protein of 20, a number of transitions or fragment ions per peptide of 6 , more than $95 \%$ to peptide confidence threshold and less than $1 \%$ to FDR. After peptide detection, peptides were aligned among different samples using high confidence detected peptides from the library. Peptides with the correlated retention time were extracted using the cited processing set with 10 min Extracted Ion Chromatogram extraction. A total of 6 samples were analysed and 643 seminal plasma and 1362 sperm proteins were quantified.

The proteomics data and result files from the analysis have been deposited with the ProteomeXchange Consortium (Vizcaíno et al., 2014) via the PRIDE partner repository (data identifier PXD015510 and PXD015516 and, PXD015511 and PXD015517 for sperm and seminal plasma data, respectively).

Bioinformatics analysis of identified plasma and sperm proteins was performed using the comprehensive bioinformatics tool for functional annotation UniProt $\mathrm{KB}$ database (www.uniprot.org) in combination with David Functional Annotation Tool (version 6.8; October 2016).

\subsection{Fertility parameters. Artificial insemination}

A total of 311 crossbreed does were inseminated in three replicates, 159 inseminated with seminal doses of G21V group and 152 with seminal doses of G39V group. Ten males per experimental group were used. 


\subsubsection{Semen collection and evaluation}

Two ejaculates per male were collected in each replica using an artificial vagina. The percentage of motile, abnormal and normal apical ridge and sperm production were evaluated as described above. Only white ejaculates were used.

\subsubsection{Semen extension}

After semen evaluation, ejaculates form each group were pooled and extended with TCG to $40 \mathrm{million} / \mathrm{mL}$. The semen was diluted at room temperature $\left(20^{\circ}-25^{\circ} \mathrm{C}\right)$.

\subsubsection{Insemination procedure}

All females used in this experiment were multiparous crossbred does and were synchronized with $12 \mathrm{UI}$ eCG injected intramuscularly $60 \mathrm{~h}$ before they were inseminated. Insemination was carried out $10-12^{\text {th }}$ day post-partum and females were induced to ovulate using a synthetic analogue of GnRH (1 $\mu \mathrm{g}$ of buserelin acetate, Hoechst) injected intramuscularly. Twenty million total sperm/female were inseminated $(0.5 \mathrm{ml}$ of semen/doe), using a plastic curved pipette. Females were randomly assigned.

Kindling rate (number of does giving birth/number of inseminated does) and prolificacy (number of total kits born) were the reproductive performances considered.

\subsection{Statistical analyses}

To analyse the effect of generation on semen characteristics, a mixed linear model was used. The generation $(\mathrm{G})$ and batch $(\mathrm{B})$ were taken as fixed effects, the male weight (W) as a covariable and litter of origin (CO) and the male (M) as random effects.

The mixed model used for the semen traits was:

$$
Y_{i j k m l}=\mu+G_{i}+B_{j}+W_{k}+C O_{l}+M_{m}+\varepsilon_{i j k m l}
$$

, where $Y_{i j k m l}$ is a record of the semen trait measured in the each male, $\mu$ is the overall mean for each trait, $\mathrm{G}_{\mathrm{j}}$ is the fixed effect of generation with two levels (G21V and G39V), $B_{i}$ is the fixed effect of the batch in which the ejaculate was collected with 10 levels, as covariable $W_{k}$ 
is the weight of the male at the evaluation, $C O(M m)_{l}$ is the random effect of the litter in which the male was born, $\mathrm{M}$ is the male and $\Sigma_{i j k m l}$ is the residual.

A generalized linear model including male group (G21V and G39V) as fixed effect was performed to compare litter size. For kindling rate, a probit link with binomial error distribution was used in the analysis, assigning 1 to pregnant and delivery does and 0 to non-pregnant and non-delivery does.

A p-value less than 0.05 was considered to indicate a statistically significant difference. The data are shown as least square mean \pm standard error mean. Statistical analyses were carried out using a commercially available software program (SPSS 21.0 software package; SPSS Inc., Chicago, Illinois, USA, 2002).

For plasma and sperm protein analysis, Multiexperiment Viewer (MeV software, Saeed et al., 2003) was used for statistical normalization following the software instructions. A t-test was used to identify the differentially expressed plasma and sperm proteins among the six ejaculate pools. Analysis was done only on proteins identified in all sperm samples. Proteins were considered differentially expressed with an adjusted p-value $<0.05$ and those with a fold change $(\mathrm{FC}) \geq 1.5$ after $\log 2$ transformation were highlighted. Inferno software was used to perform DA-PLS among samples and ClustVis software was used for the Heat Map clustering of differentially expressed proteins (DEPs). Functional annotation of DEPs, enrichment analysis of their associated gene ontology terms (GO terms) and the Kyoto Encyclopedia of Genes and Genomes (KEGG) pathways analysis were computed using the Bioinformatic software: David Functional Annotation Tool (version 6.8; October 2016), considering a p-value $<0.05$. 


\section{Results}

\subsection{Ejaculates and sperm traits}

A different percentage of males between experimental groups responded to artificial vagina stimulus $(\mathrm{P}<0.05$, data not shown in tables). The percentage of non-responding males was greater in G21V group (7/18, 38.9\% versus $2 / 21,9.5 \% \mathrm{G} 39 \mathrm{~V})$.

Of males responding to artificial vagina stimulus, 105 and 213 ejaculates were obtained from the G21V and G39V groups, respectively, of which $13(12.4 \%)$ and $23(10.8 \%)$ were discarded due to the presence of urine, debris or faeces in the G21V and G39V groups, respectively.

Only the percentage of abnormal sperm showed significant differences, being lower in G21V (10.5 \pm 2.63 versus $23.8 \pm 1.98)$. The remaining seminal parameters were similar between groups (Table 1).

\subsection{Plasma and sperm proteome}

Sperm parameters of three ejaculated pools used in the proteome analysis and fertility assay are shown in Table 2.

For both generations, 643 plasma proteins were reported. Three hundred and ninetyseven identified proteins belonged to Oryctolagus cuniculus taxonomy. The results of the sperm proteome comparison between both generations (G21V and G39V) are shown in Figure 2a. Discriminant Analysis (DA-PLS) classified the six sperm samples into two different main clusters corresponding to both groups analysed. The analysis showed differences of relative abundance in 64 proteins (Supplementary table 1). Of the total, 56 proteins were overexpressed in G39V (87.5\%). Hierarchical clustering and heat map of differential seminal plasma proteins are shown in Figure 3a, observing two main clusters associated with the experimental groups (G21V and G39V). GO term of molecular function, biological process and cell components are shown in Figure 4a, demonstrating that protein functions related to binding and catalytic activity 
were mainly affected (37.2 and $43.0 \%$ respectively). Biological regulation, metabolic and cellular process presented more than $54 \%$ of differential plasma proteins. KEGG pathway analysis showed glutathione metabolism affected in seminal plasma proteome (gammaglutamylcyclotransferase, glutathione S-transferase mu 2 and glutathione S-transferase mu 3) Sperm proteome reported 1360 proteins. DA-PLS analysis showed a clear effect of the generation (Figure 2b). Results showed a total of 132 differentially abundant proteins (Supplementary table 2). Of the total, 89 proteins were overexpressed in G39V $(67.4 \%)$. Hierarchical clustering of differential sperm proteins and heat map and GO annotation of molecular function, biological process and cells components are shown in Figure $3 \mathrm{~b}$ and $4 \mathrm{~b}$, respectively. Figure $3 b$ shows a hierarchical clustering with two main clusters associated with experimental groups (G21V and G39V) and Figure 4b reveals that proteins related to binding and catalytic activity were mainly affected (36.8 and $37.4 \%$ respectively). Biological regulation, metabolic and cellular process presented more than $53 \%$ of differential plasma proteins (Figure 4b). KEGG pathway analysis showed non-specific routes such pancreatic secretion (ATPase $\mathrm{Na}+/ \mathrm{K}+$ transporting subunit beta 3 and ATPase plasma membrane $\mathrm{Ca} 2+$ transporting 4), Renin-angiotensin system (ATPase $\mathrm{H}+$ transporting accessory protein 2 angiotensin I converting enzyme) and Proximal tubule bicarbonate reclamation (ATPase $\mathrm{Na}+/ \mathrm{K}+$ transporting subunit beta 3 and carbonic anhydrase 2 ).

Of the 64 and 133 differentially abundant proteins of plasma and sperm, 19 and 26 had a FC>1.5, 12 and 13 of them belonging to the Oryctolagus cuniculus taxonomy, respectively (Table 3a and b). Moreover, of the total of 197 differentially abundant proteins, 10 were present in both plasma and sperm proteome and 7 of them were less abundant in G21V, highlighting proteins such as Carbonic anhydrase 2, Glutathione S-transferase or Izumo family member 4. Two of them, Chromosome 16 open reading frame 89 and uncharacterized protein (U3KNX0), were overabundant. 


\subsection{Fertility parameters}

According to the characteristics of the ejaculates from the two experimental groups, seminal doses differed only in the abnormal sperm percentage (Table 2). Kindling rate, total litter size and live born were similar for both generational groups. Sixty-eight per cent of inseminated does became pregnant and gave birth (kindling rate), the total litter size was 11.8 and live litter size was 10.7 (Table 4).

\section{Discussion}

In accordance with Piles et al. (2013), selection for average daily gain does not seem to be genetically correlated with the majority of seminal traits and male fertility. Unexpectedly, the percentage of discarded animals (unable to adapt to the artificial vagina) is higher for males of the younger G21V group than for those of G39V (38.9\% vs 9.5\%). Brun et al. (2006) did not observe differences in sexual behaviour at semen collection between divergent lines selected by growth rate. Male libido measured as successful collection rate seems to be lowly heritable and more strongly affected by management practices rather than genetic selection (Tussell et al., 2012). In this study, only abnormal sperm percentage showed significant differences as a consequence of the selection for daily gain in fattening period, being $12 \%$ higher after 18 generations of selection. This result coincides with the estimated heritability of 0.19 and a positive genetic correlation of 0.25 calculated for this trait in this paternal line by Lavara et al. (2012). Moreover, the increased percentage of abnormal sperm in this study corroborates earlier findings. Thus, Vicente et al. (2004) and Lavara et al. (2005) obtained similar percentages of abnormal sperm using males belonging to the $18^{\text {th }}$ generation, while Safaa et al. (2008) and Lavara et al. (2012) after 6-7 generations (24-25 ${ }^{\text {th }}$ ) observed increased percentages (17 to 20\%) more closely to those of the current generation. No differences were observed in other sperm parameters after 18 generations, perhaps because parameters such as concentration, volume, 
and sperm production have a positive but low heritability, while motility parameters showed low heritability and an uncorrelated response to selection (Lavara et al., 2011; Tusell et al., 2012).

Abnormal sperm might be associated with worsening of the spermatogenesis process and linked to the poor reproductive performance of does. High failures in ovulation frequency and gestational losses related with deficient LH, 17ß-estradiol and progesterone production and alterations in the insulin growth factor system were observed in females from this paternal line (Llobat et al. 2012, Vicente et al., 2012, Naturil-Alfonso et al., 2016).

Seminal plasma and sperm proteome showed that the generational step increased the abundance of most of the differentially expressed proteins ( $87.5 \%$ and $66.9 \%$, respectively). Moreover, highlighting proteins differentially expressed with $\mathrm{FC}>1.5$ and focusing on Oryctolagus cuniculus taxonomy, fourteen critical proteins related with the sperm functions were affected by selection for growth rate ( 9 and 5 from plasma and sperm proteome, respectively). Sperm leave the testes morphologically defined but lacking motility, as well as crucial proteins involved in oocyte binding and fertilization. Key proteins related to motility or later to interaction with the egg surface are added to the sperm membrane in the epididymis and, moreover, at the time of ejaculation, seminal plasma proteins from accessory glands coat the sperm surface and stabilize the membrane, inhibiting fertilization ability (Gervasi and Visconti, 2018). The G21V group showed overabundant proteins, such as transmembrane serine protease 2 (TMPRSS2), chromosome 16 open reading frame 89 and uncharacterized protein (U3KNX0). The first of them has been found in human seminal prostasomes (Kim et al., 2006; Antalis et al., 2011), and rabbit seminal plasma is also rich in seminal vesicles produced and secreted by the prostate to prevent sperm capacitation (Davis et al., 1983, Castellini et al., 2006 and 2012). The function of the second is unknown, but a predicted functional partner is Ropporin-1A, a pKA-dependent signalling protein involved in sperm 
motility and prominent in capacitated spermatozoa (Rahman et al., 2017), and the third has high homology with WGA16, a prostate-derived seminal plasma glycoprotein that is deposited on the sperm surface at the moment of ejaculation to prevent premature capacitation (Garénaux et al., 2015; Pérez-Patiño et al., 2018). In contrast, another 6 seminal sperm proteins involved in immunoprotection (G1TIY2 and uteroglobin), capacitation (serpin family, uteroglobin, importin 5, carbonic anhydrase II) and membrane fusion (protein disulfide isomerase family A member 6) and consequently in fertilization process were less abundant. It has been suggested that G1TIY2, an IgG that was detected in lumen of epididymis, accessory glands and spermatozoa in rabbit (Weininger et al. 1982), would play a role of immunoprotection in fertilization (Yan et al., 2016). Uteroglobin is related to suppression of sperm antigenicity and capacitation-inhibiting activity (Luconi et al., 2000). Serpin family proteins are inhibitors of several serine proteases which would reinforce the effect of TMPRSS2 overexpression (Law et al., 2006). Importins, originally characterized for their central role in protein transport through the nuclear pores, contribute to the formation of subcellular domains in sperm during the maturation as acrosome (Loveland et al., 2015). Protein disulfide isomerase family A member 6 are involved in the activation of membrane fusion and required fertilization process (Ellerman et al., 2006). Carbonic anhydrase II regulates HCO3- homeostasis in sperm and the composition in genital tract fluids, affecting sperm motility and capacitation for what is required for normal fertilization (Liao et al., 2009; Wandernoth et al., 2015)

Sperm proteome showed several remarkable proteins whose abundance has been modified and they are mainly related with sperm maturation, morphology and motility. Among the overabundant ones, in addition to chromosome 16 open reading frame 89 and U3KNX0RABIT in G21V already found in seminal plasma proteome, we observed a protein from the lipocalin family strongly expressed (U3KNB5_RABIT) and involved in sperm maturation. This protein family is a carrier of small hydrophobic ligands (fatty acids, steroids, thyroid hormones, 
retinoids, etc.), and several members were reported to be associated with poor semen parameters such as decreased sperm count, percentage of motility, and percentage of normal morphology when their level is diminished (Gerena et al., 1998; Leone et al, 2002; Samanta et al., 2018). Finally, in this overabundant group, Zeta globin was correlated with the percentage of cells with both membrane and acrosome damaged in rabbit sperm (Arruda-Alencar et al., 2012). Among the least abundant proteins in G21V male group are carbonic anhydrase, already observed in the plasma proteome Fam71f1 (Family with sequence similarity 71 member C). This protein family has been identified in sperm nucleus and tail (Kwon et al., 2017; Ma et al., 2017) and has predicted functional partners related with spermatogenesis and motility. ATPase $\mathrm{H}+$ transporting accessory protein 2 is an ATP-dependent proton pump that acidifies intracellular compartments and is negatively correlated with asthenozoospermia, in a similar way to carbonic anhydrase (Peralta-Arias et al., 2015; Lestari et al., 2017). This last protein was identified with ATPase plasma membrane Ca2 + transporting 4 and carbonic anhydrase in the KEGG pathways renin-angiotensin system and proximal tubule bicarbonate reclamation, respectively. These ATPases and carbonic anhydrase play a main role in hyperactivity, capacitation and acrosome reaction by regulating intracellular $\mathrm{pH}$, membrane potential and intracellular calcium release (Freitas et al., 2017; Thundathil et al., 2018). However, no effect has been observed between the groups of males on total motility or on the speed and trajectory parameters in the present study. UDP-glucose glycoprotein glucosyltransferases (UGGT 1 and 2) are central components of the endoplasmic reticulum glycoprotein-folding quality control system. UGGT expression is increased through stress and has been observed to be predominantly up-regulated in the semen of infertile men (Cadavid et al. 2014).

Finally, overabundance of KIAA1324 protein has been observed in teratozoospermic human (Choucair, 2018), and, accordingly, this protein was less abundant in semen samples of G21V and overabundant in the G39V male group, and could contribute together with the 
lipocalin family protein to high levels of abnormal spermatozoa observed in males from this latter male group.

Despite the changes produced by growth rate in abnormal sperm or ejaculate proteome, no differences were observed in pregnancy and prolificacy rates when seminal doses of both experimental groups were used to inseminated crossbred females. It seems that the 14 proteins related with capacitation and fertilization function affected by selection for growth rate had no impact on the results of insemination. The commercial seminal dose used (20 million spermatozoa $/ \mathrm{ml}$ ) would compensate for the potential deleterious effects of these differences. Viudes de Castro and Vicente, (1997) showed that commercial seminal doses of about 4 sperm millions are enough to obtain normal pregnancy and prolificacy rates. How the changes produced by growth selection in the ejaculate proteome can alter the fertilizing capacity of the semen at a level that is appreciable by the rabbit farmers and insemination centres is difficult to assess in a species in which the seminal doses are heterospermic and the amount of sperm per dose is at least 5 times higher than necessary to guarantee the fertility and prolificacy of rabbits. A more restrictive assay with individual males and low sperm doses might define the importance of modifications introduced by genetic selection.

In conclusion, our study reveals how the effect of selection schemes for daily average gain in a paternal line (R line) increases over abnormal sperm and alters seminal plasma and sperm proteome. Some proteomic changes may be related to the increasing abnormal sperm rate observed, but no effects on fertility and prolificacy were observed after insemination with commercial semen doses.

\section{Acknowledgements}

This research was supported by AGL2017-85162-C2-1-R research project funded by Ministerio de Economía, Industria y Competitividad (MICINN, Spain). X Garcia-Dominguez was 
503

504

505

506

507

508

509

510

511

512

513

514

515

516

517

518

519

520

521

522

523

524

525

526

527

supported by a research grant from MICINN (BES-2015-072429). English text version was revised by N. Macowan English Language Service.

\section{References.}

Antalis, T.M., Bugge, T.H., Wu, Q., 2011. Membrane-anchored serine proteases in health and disease. Prog Mol Biol Transl Sci. 99,1-50. https://doi.org/ 10.1016/B978-0-12-385504$6.00001-4$

Arruda-Alencar, J.M., Viana-Neto, A.M., Souza, C.E.A., Martins, J. A. M., Moreno, F. B., Moreira, A. C. O., Guerreiro, M. E. F., Moura, A. A., 2012. Major proteins of the seminal plasma of New Zealand White rabbits and association with semen criteria. Proceedings 10th World Rabbit Congress. 295-299.

Bezerra, M.J.B., Arruda-Alencar, J.M., Martins, J.A.M., Viana, A.G.A., Viana Neto, A.M., Rêgo J.P.A., Oliveira „R.V., Lobo, M., Moreira, A.C.O., Moreira, R.A., Moura, A.A, 2019. Major seminal plasma proteome of rabbits and associations with sperm quality. Theriogenology. 128, 156-166. https://doi.org/10.1016/j.theriogenology.2019.01.013

Brun, J.M., Theau-Clément, M., Bolet, G., 2002. The relationship between rabbit semen characteristics and reproductive performance after artificial insemination. Anim. Reprod. Sci. 70 (1-2), 139-149. https://doi.org/10.1016/S0378-4320(01)00197-X.

Brun, J.M., Theau-Clément, M., Esparbie, J., Falieres, J., Saleil, G., Larzul, C., 2006. Semen production in two rabbit lines divergently selected for 63-d body weight. Theriogenology. 66, 2165-2172. 
531

https://doi.org/10.1016/j.theriogenology.2006.07.004.

Brun, J.M., Sanchez, A., Ailloud, E., Saleil, G., Theau-Clément, M., 2016. Genetic parameters of rabbit semen traits and male fertilising ability. Anim. Reprod. Sci. 166, 15-21. https://doi.org/10.1016/j.anireprosci.2015.12.008.

Bunger, L., Lewis, R.M., Rothschild, M.F., Blasco, A., Renne, U., Simm, G., 2005. Relationships between quantitative and reproductive fitness traits in animals. Philos. Trans. R. Soc. Lond. B. Biol. Sci., 360, 1489-1502. https://doi.org/10.1098/rstb.2005.1679.

Cadavid, J. A.P., Alvarez, A., Markert, U.R., Maya, W.C., 2014.Differential protein expression in seminal plasma from fertile and infertile males. J. Hum. Reprod. Sci. 4 (7), 206-211. http://www.jhrsonline.org/text.asp?2014/7/3/206/142485.

Casares-Crespo, L., Fernández-Serrano, P., Vicente, J.S., Marco-Jiménez, F., Viudes-deCastro, M.P., 2018. Rabbit seminal plasma proteome: The importance of the genetic origin. Anim. Reprod. Sci. 189, 30-42. https://doi.org/10.1016/j.anireprosci.2017.12.004.

Casares-Crespo, L., Fernández-Serrano, P., Viudes-de-Castro, M.P., 2019. Proteomic characterization of rabbit (Oryctolagus cuniculus) sperm from two different genotypes. Theriogenology.128,140-148.

https://doi.org/10.1016/j.theriogenology.2019.01.026.

Castellini, C., Lattaioli, P., Moroni, M., Minelli, A., 2000. Effect of seminal plasma on the characteristics and fertility of rabbit spermatozoa. Anim. Reprod. Sci. 63, 275-282. 
553

554

555

556

557

558

559

560

561

562

563

564

565

566

567

568

569

570

571

572

573

574

575

576

577

https://doi.org/10.1016/S0378-4320(00)00181-0.

Castellini, C., Cardinali, R., Dal Bosco, A., Minelli, A., Camici, O., 2006. Lipid composition of the main fractions of rabbit semen. Theriogenology. 65, 703-712. http://dx.doi.org/10.1016/j.theriogenology.2005.05.053.

Castellini, C., Mourvaki, E., Cardinali, R., Collodel, G., Lasagna, E., Del Vecchio, M.T., Dal Bosco, A., 2012. Secretion patterns and effect of prostate-derived granules on the sperm acrosome reaction of rabbit buck. Theriogenology. 78 (4) 715-723. http://dx.doi.org/10.1016/j.theriogenology.2012.02.012

Courtens, J.L., Bolet, G., Theau-Clément, M., 1994. Effect of acrosome defects and sperm chromatin decondensation on fertility and litter size in the rabbit. Preliminary electronmicroscopic study. Reprod. Nutr. Dev. 34, 427-437. https://doi.org/10.1051/rnd:19940504

Choucair, F., 2018. Unraveling the sperm transcriptome by nextgeneration sequencing and the global epigenetic and landscape in infertile men. Molecular Biology.Université Côted' Azur; Université libanaise, NNT:2018AZUR4058. https://tel.archives-ouvertes.fr/tel-01958881

Davis, B.K., Davis, N.V., 1983. Binding by glyproteins of seminal plasma vesicles accelerates decapacitation in rabbit spermatozoa. Biochimica et Biophysica Acta. 727(1), 70-76. https://doi.org/10.1016/0005-2736(83)90370-X.

Ellerman, D.A., myles, D.G., Primakoff, P., 2006. A role for sperm surface protein disulfide isomerase activity in gamete fusion: evidence for the participation of erp57. Developmental 
590

591

592

593

594

595

596

597

598

599

600

601 602

Cell. 10, 831-837. https://doi.org/10.1016/j.devcel.2006.03.011.

Estany, J., Camacho, J., Baselga, M., Blasco, A., 1992. Selection response of growth rate in rabbits for meat production. Genet. Sel. Evol. 24, 527-537. https://doi.org/10.1186/1297-968624-6-527.

Freitas, M.J., Vijayaraghavan, S., Fardilha, M., 2017. Signaling mechanisms in mammalian sperm motility. Biol. Reprod. 96(1), 2-12. https://doi.org/10.1095/biolreprod.116.144337

García-Tomás, M., Sánchez, J., Rafel, O., Ramon, J., Piles, M., 2006a. Variability, repeatability and phenotypic relationships of several characteristics of production and semen quality in rabbit. Anim. Reprod. Sci. 93, 88-100. https://doi.org/10.1016/j.anireprosci.2005.06.011.

García-Tomás, M., Sánchez, J., Rafel, O., Ramon, J., Piles, M., 2006b. Heterosis, direct and maternal genetic effects on semen quality traits of rabbits. Livest. Sci. 100, 111-120. https://doi.org/10.1016/j.livprodsci.2005.08.004.

Garénaux, E., Kanagawa, M., Tsuchiyama, T., Hori, K., Kanazawa, T., Goshima, A., Chiba, M., Yasue, H., Ikeda, A., Yamaguchi, Y., Sato, C., Kitajima, K., 2015. Discovery, primary, and crystal structures and capacitation related properties of a prostate-derived heparin-binding protein WGA16 from boar sperm. J. Biol. Chem. 290 (9), 5484-5501. https://doi.org/10.1074/jbc.M114.635268.

Gerena, R. L., Irikura, D., Urade, Y., Eguchi, N., Chapman, D.A., Killian, G. J., 1998. Identification of a fertility-associated protein in bull seminal plasma as lipocalin-type 
603

prostaglandin

D-synthase.

Biol.

Reprod.

58

(3),

826-833 https://doi.org/10.1095/biolreprod58.3.826.

605

606

607

608

609

610

611

612

613

614

615

616

617

618

619

620

621 https://doi.org/10.1530/jrf.0.0700219.

622

623 Kim, T. S., Heinlein, C., Hackman, R. C., Nelson, P. S., 2006. Phenotypic analysis of mice 624 lacking the Tmprss2-encoded protease. Molecular and Cellular Biology. 965-975. 625 https://doi.org/10.1128/MCB.26.3.965-975.2006.

626

627 Kwon, J.T., Ham, S., Jeon, S., Kim, Y., Oh, S., Cho, C., 2017. Expression of uncharacterized

Gervasi, M.G., Visconti, P.E., 2017. Molecular changes and signaling events occurring in sperm during epididymal maturation. Andrology. 5(2), 204-218. https://doi: 10.1111/andr.12320.

Gillet, L.C., Navarro, P., Tate, S., Röst, H., Selevsek, N., Reiter, L., Bonner, R. Aebersold, R., 2012. Targeted data extraction of the MS/MS spectra generated by data-independent acquisition: a new concept for consistent and accurate proteome analysis. Mol. Cell. Proteomics. 11, 6. https://doi.org/10.1074/mcp.O111.016717

Hagen D.R., Gilkey A.L., Foote R.H., 2002. Spermatozoal velocity andmotility and its relationship to fertility in the rabbit inseminated withlow sperm numbers. World Rabbit Sci. 10: 135-140. https://doi.org/10.4995/wrs.2002.485.

Jeyendran R.S., Van der Ven H.H., Perez-Pelaez M., Crabo B.G., Zaneveld L.J.D., 1984. Development of an assay to assess the functional integrity of the human sperm membrane and its relationship to other semen characteristics. J. Reprod. Fertil. 70, 219-228.

Kwon, J.T., Ham, S., Jeon, S., Kim, Y., Oh, S., Cho, C., 2017. Expression of unchatarized 
628

629

630

631

632

633

634

635

636

637

638

639

640

641

642

643

644

645

646

647

648

649

650

651

652

male germ cell-specific genes and discovery of novel sperm-tail proteins in mice. PLoS ONE. 12(7): e0182038. https://doi.org/10.1371/journal.pone.0182038.

Larzul, C., Gondret, F., Combes, S., de Rochambeau, H., 2005. Divergent selection on 63-day body weight in the rabbit: response on growth, carcass and muscle traits. Genet. Sel. Evol. 37, 105-122. https://doi.org/10.1186/1297-9686-37-1-105.

Lavara, R., Mocé, E., Lavara, F., Viudes De Castro, M.P., Vicente, J.S., 2005. Do parameters of seminal quality correlate with the results of on-farm inseminations in rabbits? Theriogenology. 64, 1130-1141. https://doi.org/10.1016/j.theriogenology.2005.01.009.

Lavara, R., Vicente, J.S., Baselga, M., 2011. Genetic parameter estimates for semen production traits and growth rate of a paternal rabbit line. J. Anim. Breed. Genet. 128, 44-51. https://doi.org/10.1111/j.1439-0388.2010.00889.x.

Lavara, R., Vicente, J.S., Baselga, M., 2012. Estimation of genetic parameters for semen quality traits and growth rate in a paternal rabbit line. Theriogenology. 78, 567-575. https://doi.org/10.1016/j.theriogenology.2012.03.002.

Lavara, R., Vicente, J.S., Baselga, M., 2013. Genetic variation in head morphometry of rabbit sperm. Theriogenology. 80, 313-318. https://doi.org/10.1016/j.theriogenology.2013.04.015.

Law, R.H., Zhang, Q., McGowan, S., Buckle, A.M., Silverman, G.A., Wong, W., Rosado, C.J., Langendorf, C.G., Pike, R.N., Bird, P.I., Whisstocklaw, J.C., 2006. An overview of the serpin superfamily. Genome Biology. 7, 216. https://doi.org/10.1186/gb-2006-7-5-216. 
654 Leone, M.G., Haq, H.A:, Saso, L., 2002. Lipocalin type prostaglandin D-synthase: which role 655 in male fertility?. Contraception. 65, 293-295. https://doi.org/10.1016/S0010-7824(02)002806569

657

Lestari, S.W., Miati, D.N., Seoharso, P., Sugiyanto, R., Pujianto, D.A., 2017. Sperm Na+, K+659 ATPase $\alpha 4$ and plasma membrane Ca2+-ATPase (PMCA) 4 regulation in asthenozoospermia. 660 Systems Biology in Reproductive Medicine. 63 (5), 294-302.

661

662

663

664

665

666

667

668

669

670

671

672

673

674

675

676

677 https://doi.org/10.1080/19396368.2017.1348565.

Liao, T.T., Xiang, Z., Zhu, W.B., and Fan, L.Q., 2009. Proteome analysis of round-headed and normal spermatozoa by 2-D fluorescence difference gel electrophoresis and mass spectrometry. Asian J. Androl. 11, 683-693. https://doi.org/10.1038/aja.2009.59

Llobat, L., Marco-Jiménez, F., Peñaranda, D.S., Thieme, R., Navarrete, A., Vicente, J.S., 2012. mRNA expression in rabbit blastocyst and endometrial tissue of candidate genes involved in gestational losses. Reprod. Domest. Anim. 47, 281-287. https://doi.org/10.1111/j.14390531.2011.01855.x.

Loveland, K.L., Major, A.T., Butler, R., Young, J.C., Jans, D.A., Miyamoto, Y., 2015. Putting things in place for fertilization: discovering roles for importin proteins in cell fate and spermatogenesis Asian Journal of Andrology. 17, 537-544. https://doi.org/10.4103/1008$682 X .1543101$

Luconi, M., Muratori, M., Maggi, M., Pecchioli, P., Peri, A., Mancini, M., Filimberti, E., Forti, 
680

681

682

686

687

688

689

690

691

692

693

694

695

696

697

698

699

700

701

702

G., Baldi, E., 2000. Uteroglobin and transglutaminase modulate human sperm functions. J. Androl. 21(5), 676-688. https://doi.org/10.1002/j.1939-4640.2000.tb02136.x

Lukefahr, S.D., Odi, H.B., Atakora, J.K.A., 1996. Mass selection for 70-day body weight in rabbits. J. Anim. Sci. 74, 1481-1489. https://doi.org/10.2527/1996.7471481x

Ma, Q., Li, Y., Luo, M., Guo, H., Lin, S., Chen, J., Du, Y., Jiang, Z., Gui, Y., 2017.The expression characteristics of FAM71D and its association with sperm motility, Human Reproduction. 32 (11), 2178-2187. https://doi.org/10.1093/humrep/dex290

Marai, I.F.M., Habeeb, A.A.M., Gad, A.E. Rabbits' productive, reproductive and physiological performance traits as affected by heat stress: a review. Livest Prod Sci. 2002, 78:71-90. https://doi.org/10.1016/S0301-6226(02)00091-X.

Mocé, E., Vicente, J.S., Lavara, R., 2003. Effect of freezing-thawing protocols on the performance of semen from three rabbit lines after artificial insemination. Theiogenology. 60(1), 115-123. https://doi.org/10.1016/S0093-691X(02)01329-8.

Naturil-Alfonso, C., Lavara, R., Millán, P., Rebollar, P.G., Vicente, J.S., Marco-Jiménez, F., 2016. Study of failures in a rabbit line selected for growth rate. World Rabbit Sci. 24, 47-53. https://doi.org/10.4995/wrs.2016.4016

Nizza, A., Di Meo, C., Taranto, S., 2003. Effect of collection rhythms and season on rabbit semen production. Reprod. Domest. Anim. 38(6), 436-439. https://doi.org/10.1046/j.14390531.2003.00458.x 
703

704

705

706

707

708

709

710

711

712

713

714

715

716

717

718

719

720

721

722

723

724

725

726

727

Osada, T., Watanabe, G., Kondo S., Toyoda, M., Sakaki, Y., Takeuchi, T., 2001. Male reproductive defects caused by puromycin-sensitive aminopeptidase deficiency in mice. Mol Endocrinol. 15, 960-971. https://doi.org/10.1210/mend.15.6.0643.

Pascual, J.J., Claudia García, C., Martínez, E., Mocé, E., Vicente, J.S., 2004 Rearing management of rabbit males selected by high growth rate: the effect of diet and season on semen characteristics. Reprod. Nutr. Dev. 44, 49-63. https://doi.org/10.1051/rnd:2004016.

Pascual, J.J., Marco-Jiménez, F., Martínez-Paredes, E., Ródenas, L., Fabre, C., Juvero, M.A., Cano, J.L., 2016. Feeding programs promoting daily feed intake stability in rabbit males reduce sperm abnormalities and improve fertility. Theriogenology. 86(3), 730-737.

https://doi.org/10.1016/j.theriogenology.2016.02.026.

Pérez-Patiño, C., Parrilla, I., Li, J., Barranco, I., Martínez, E.A., Rodriguez-Martínez, H., Roca, J., 2018. The proteome of pig spermatozoa is remodeled during ejaculation. Mol. Cell. Proteomics. 18(1), 41-50. https://doi.org/10.1074/mcp.RA118.000840

Peralta-Arias, R., Vívenes, C., Camejo, M., Piñero, S., Proverbio, T., Martínez, E., Marín, R., Proverbio, F., 2015. ATPases, ion exchangers and human sperm motility, Reproduction. 149(5), 475-484. https://doi.org/10.1530/REP-14-0471

Piles, M., Tusell, L., 2012. Genetic correlation between growth and female and male contributions to fertility in rabbit. J. Anim. Breed. Genet. 129, 298-305. https://doi.org/10.1111/j.1439-0388.2011.00975.x. 
741

Piles, M., Mocé, M.L., Laborda, P., Santacreu, M.A., 2013. Feasibility of selection for male contribution to embryo survival as a way of improving male reproductive performance and semen quality in rabbits. J. Anim. Sci. 91, 4654-4658. https://doi.org/10.2527/jas.2013-6446.

Rahman, M.S., Kwon, W., Pang, M., 2017. Prediction of male fertility using capacitationassociated proteins in spermatozoa. Mol. Reprod. Dev. 84 (9), 749-759. https://doi.org/10.1002/mrd.22810.

Roca J., Martínez S., Orengo J., Parrilla I., Vazquez J.M., Martínez E.A. 2005. Influence of constant long days on ejaculate parameters of rabbits reared under natural environment conditions of Mediterranean area. Livest. Prod. Sci. 94: 169-177. https://doi.org/10.1016/j.livprodsci.2004.10.011.

Rochambeau, H., Fuente, L.F., Rouvier, R.,1989. Sélection sur la vitesse de croissance postsevrage chez le lapin. Genet. Sel. Evol. 21, 527-546. https://doi.org/10.1186/1297-968621-4-527.

Saeed, A.I., Sharov, V., White, J., Li, J., Liang, W., Bhagabati, N., Braisted, J., Klapa, M., Currier, T., Thiagarajan, M., Sturn, A., Snuffin, M., Rezantsev, A., Popov, D., Ryltsov, A., Kostukovich, E., Borisovsky, I., Liu, Z., Vinsavich, A., Trush, V., Quackenbush, J., 2003. TM4: a free, open-source system for microarray data management and analysis. Biotechniques. 34, 374-378. https://doi.org/10.2144/03342mt01.

Samanta, L., Parida, R., Dias. T.R., Agarwalet, A., 2018. The enigmatic seminal plasma: a proteomics insight from ejaculation to fertilization. Reprod Biol Endocrinol. 16:41. 
753

754

755

756

757

758

759

760

761

762

763

764

765

766

767

768

769

770

771

772

773

774

775

776

777

https://doi.org/10.1186/s12958-018-0358-6.

Sabés-Alsina, M., Planell, N., Torres-Mejia, E., Taberner, E., Maya-Soriano, MJ., Tusell, L., Ramon, J., Dalmau, A., Piles, M., Lopez-Bejar, M., 2015. Daily exposure to summer circadian cycles affects spermatogenesis, but not fertility in an in vivo rabbit model. Theriogenology. 83, 246-252. https://doi.org/10.1016/j.theriogenology.2014.09.013

Safaa, H.M., Vicente, J.S., Lavara, R., Viudes de Castro, M.P., 2008. Semen evaluation of two selected lines of rabbit bucks. World Rabbit Sci. 16, 141-148. https://doi.org/10.4995/wrs.2008.622

Shevchenko, A., Jensen, O.N., Podtelejnikov, A.V., Sagliocco, F., Wilm, M., Vorm, O., Mortensen, P., Boucherie, H., Mann, M., 1996. Linking genome and proteome by mass spectrometry: large-scale identification of yeast proteins from two dimensional gels. PNAS. 93, 14440-14445. https://doi.org/10.1073/pnas.93.25.14440

Shilov, I.V., Seymour, S.L., Patel, A.A., Loboda, A., Tang, W.H., Keating, S.P., Hunter, C.L., Nuwaysir, L.M., Schaeffer, D.A., 2007. The Paragon Algorithm, a next generation search engine that uses sequence temperature values and feature probabilities to identify peptides from tandem mass spectra. Mol. Cell. Proteomics. 6, 1638-1655. https://doi.org/10.1074/mcp.T600050-MCP200

Theau-Clément, M., Bolet, G., Sanchez, A., Saleil, G., Brun, J.M., 2015. Some factors that influence semen characteristics in rabbits. Anim. Reprod. Sci. 157, 33-38. https://doi.org/10.1016/j.anireprosci.2015.03.011. 
779 Thundathil, J.C., Rajamanickam, G.D., Kastelic, J.P., 2018. Na/K-ATPase and regulation of

780

781

782

783

784

785

786

787

788

789

790

791

792

793

794

795

796

797

798

799

800

801

802

sperm function. Anim. Reprod. 15(1), 711-720. https://doi.org/10.21451/1984-3143-AR2018-

0024.

Tusell, L., Legarra, A., Garciia-Tomas, M., Rafel, O., Ramon, J., Piles, M., 2012 Genetic basis of semen traits and their relationship with growth rate in rabbits. J. Anim. Sci. 90, 1385-1397. https://doi.org/10.2527/jas2011-4165.

Vicente, J.S., Viudes de Castro, M.R., Lavara, R., Lavara, F., 2000. Effect of male line on prolificacy from does inseminated with low sperm doses. 7th World Rabbit Congress, 273-277. https://world-rabbit-science.com/WRSA-Proceedings/Congress-2000-

Valencia/Papers/Reproduction/R30-Vicente.pdf

Vicente, J.S., Viudes de Castro, M.P., Lavara, R., Mocé, E., 2004. Study of fertilising capacity of spermatozoa after heterospermic insemination in rabbit using DNA markers. Theriogenology. 61, 1357-1365.https://doi.org/10.1016/j.theriogenology.2003.08.009.

Vicente, J.S., Llobat, L., Viudes de Castro, M.P., Lavara, R., Baselga, M., Marco-Jiménez, F. 2012. Gestational losses in a rabbit line selected for growth rate. Theriogenology. 77, 81-88. https://doi.org/10.1016/j.theriogenology.2011.07.019.

Viudes de Castro, M.P., Vicente, J.S., 1997. Effect of sperm count on the fertility and prolificity rates of meat rabbits. Anim. Reprod. Sci. 46, 313-319. https://doi.org/10.1016/S03784320(96)01628-4. 
804 Viudes de Castro, M.P., Mocé, E., Lavara, R., Marco-Jiménez, F., Vicente J.S., 2014. 805 Aminopeptidase activity in seminal plasma and effect of dilution rate on rabbit reproductive

806

807 808

809

810

811

812

813

814

815

816

817

Viudes de Castro, M.P., Casares-Crespo, L., Monserrat-Martínez, A., Vicente, J.S., 2015. Determination of enzyme activity in rabbit seminal plasma and its relationship with quality semen parameters. World Rabbit Sci. 23 (4), 247-253. https://doi.org/10.4995/wrs.2015.4064.

Vizcaíno, J.A., Deutsch, E.W., Wang, R., Csordas, A., Reisinger, F., Ríos, D. et al., 2014. ProteomeXchange provides globally coordinated proteomics data submission and dissemination, Nat. Biotechnol. 30, 223-226. https://doi.org/10.1038/nbt.2841.

Wandernoth, P.M., Mannowetz, N., Szczyrba, J., Grannemann, L., Wolf, A., Becker, H.M., Sly, W.S., Wennemuth, G., 2015. Normal fertility requires the expression of carbonic anhydrases II and IV in sperm. J. Biol. Chem. 290(49), 29202-16. https://doi.org/10.1074/jbc.M115.698597.

Weininger, R.B., Fisher, S., Rifkin, J., Bedford, J.M., 1982. Experimental studies on the passage of specific IgG to the lumen of the rabbit epididymis. J. Reprod. Fert. 66, 251-258. https://doi.org/10.1530/jrf.0.0660251.

Yan, M., Zhang, X., Pu, Q., Huang, T, Xie, Q., Wang, Y., Jing, Li, Wang, Y., Gu, H., Huang, T., Li, Z., Gu, J., 2016. Immunoglobulin G expression in human sperm and possible functional 
828 significance. Sci. Rep. 6, 20166. https://doi.org/ 10.1038/srep20166

829

830

831

832 
Table 1. Seminal traits in G21V and G39V.

\begin{tabular}{|c|c|c|c|}
\hline TRAITS & $\begin{array}{c}\mathbf{N}^{\circ} \\
\text { EJACULATES }\end{array}$ & $\begin{array}{c}\text { G21V } \\
(\mathrm{LSM} \pm \mathrm{SE})\end{array}$ & $\begin{array}{c}\text { G39V } \\
(\mathrm{LSM} \pm \text { SE })\end{array}$ \\
\hline \multicolumn{4}{|c|}{ EJACULATE PARAMETERS } \\
\hline VOL (ml) & 424 & $0.58 \pm 0.06$ & $0.48 \pm 0.05$ \\
\hline CONC (x 10 $\left.{ }^{6} \mathrm{spz} / \mathrm{ml}\right)$ & 414 & $278 \pm 65.7$ & $316 \pm 47.4$ \\
\hline TSE (x 10 ${ }^{6}$ sperm) & 414 & $155 \pm 22.8$ & $144 \pm 17.0$ \\
\hline \multicolumn{4}{|c|}{ SPERM QUALITY PARAMETERS } \\
\hline MOT (\%) & 386 & $45.8 \pm 6.47$ & $50.5 \pm 4.83$ \\
\hline PROG (\%) & 386 & $25.3 \pm 4.25$ & $25.9 \pm 3.13$ \\
\hline VIAB (\%) & 379 & $72.6 \pm 3.25$ & $68.7 \pm 2.40$ \\
\hline ABN (\%) & 401 & $10.7 \pm 3.27^{\mathrm{a}}$ & $23.5 \pm 2.27^{b}$ \\
\hline NAR (\%) & 401 & $88.7 \pm 2.75$ & $90.0 \pm 2.04$ \\
\hline HOST (\%) & 380 & $68.6 \pm 4.55$ & $63.4 \pm 3.35$ \\
\hline \multicolumn{4}{|c|}{ SPERM MOTILITY PARAMETERS } \\
\hline $\operatorname{VCL}(\mu \mathrm{m} / \mathrm{s})$ & 372 & $104 \pm 4.0$ & $98.0 \pm 2.84$ \\
\hline VSL $(\mu \mathrm{m} / \mathbf{s})$ & 372 & $38.3 \pm 3.32$ & $37.6 \pm 2.31$ \\
\hline $\mathbf{V A P}(\mu \mathrm{m} / \mathrm{s})$ & 372 & $56.6 \pm 3.55$ & $55.7 \pm 2.46$ \\
\hline LIN (\%) & 372 & $38.0 \pm 2.67$ & $38.9 \pm 1.97$ \\
\hline STR (\%) & 372 & $67.8 \pm 2.15$ & $67.1 \pm 1.58$ \\
\hline WOB (\%) & 372 & $55.0 \pm 2.39$ & $56.9 \pm 1.77$ \\
\hline $\operatorname{ALH}(\mu \mathrm{m})$ & 372 & $3.1 \pm 0.18$ & $3.0 \pm 0.12$ \\
\hline BCF (Hz) & 372 & $12.9 \pm 0.74$ & $11.1 \pm 0.51$ \\
\hline
\end{tabular}
square mean \pm standard error.

VOL: Ejaculate volume; CONC: Spermatic concentration; TSE: Total sperm per ejaculate; MOT: Percentage of sperm motility; PROG: Percentage of progressive motility; VIAB: apical ridge; HOST: Hypo-osmotic swelling test; VCL: Curvilinear velocity; VSL: straight-

841 line velocity; VAP: average path velocity; LIN: linearity index; STR: straightness; WOB: wobble; ALH: amplitude of lateral head displacement; BCF: beat cross-frequency. 
844 Table 2. Seminal parameters of G21V and G39V groups used in proteome analysis and fertility 845 assay.

846

\begin{tabular}{lcc}
\hline TRAITS & $\begin{array}{c}\text { G21V } \\
(\mathbf{L S M} \pm \text { SE) }\end{array}$ & $\begin{array}{c}\text { G39V } \\
(\mathbf{L S M} \pm \text { SE) }\end{array}$ \\
\hline MOT (\%) & $68.7 \pm 6.69$ & $67.3 \pm 8.45$ \\
PROG (\%) & $49.0 \pm 6.93$ & $41.0 \pm 7.93$ \\
VIAB (\%) & $57.3 \pm 4.11$ & $62.7 \pm 6.90$ \\
ABN (\%) & $16.9 \pm 2.34^{\mathrm{a}}$ & $26.6 \pm 1,49^{\mathrm{b}}$ \\
NAR (\%) & $81.7 \pm 4.37$ & $85.6 .0 \pm 3.58$ \\
\hline
\end{tabular}

847

a, b Different superscript between rows indicate statistical differences $(\mathrm{P}<0.05)$. $\mathrm{LSM} \pm \mathrm{SE}$ : least square mean \pm standard error.

MOT: Percentage of sperm motility; PROG: Percentage of progressive motility; percentage of normal apical ridge.

852 
853

854

855

Table 3a. Highlighted differentially seminal plasma proteins between male groups (G21V and G39V) with a fold change (FC) $\geq 1.5$ after $\log _{2}$ transformation.

\begin{tabular}{clcc}
\hline Peak name & \multicolumn{1}{c}{ Protein name } & Fold Change & $\begin{array}{c}\text { p- } \\
\text { value }\end{array}$ \\
\hline G1TIY2_RABIT & Uncharacterized protein & -3.96 & 0.004 \\
G1SKP2_RABIT & Importin 5 & -2.91 & 0.046 \\
G1SQG6_RABIT & Serpin family A member 5 & -2.35 & 0.004 \\
P02779_RABIT & Uteroglobin & -2.25 & 0.003 \\
G1T4H3_RABIT & Protein disulfide isomerase family A & -2.15 & 0,049 \\
G1SPY1_RABIT & member 6 & -2.03 & 0.027 \\
G1U8K1_RABIT & Serpin domain-containing protein & -1.70 & 0.029 \\
P00919_RABIT & Carbonic anhydrase 2 & -1.63 & 0.044 \\
G1SNK5_RABIT & Uncharacterized protein & -1.55 & 0.019 \\
G1TMY8_RABIT & Transmembrane serine protease 2 & 1.52 & 0.035 \\
G1T0A6_RABIT & Chromosome 16 open reading frame 89 & 2.21 & 0.031 \\
U3KNX0_RABIT & Uncharacterized protein & 2.41 & 0.015 \\
\hline
\end{tabular}

Table 3b. Highlighted differentially sperm proteins between male groups (G21V and G39V) with a fold change $(\mathrm{FC}) \geq 1.5$ after $\log _{2}$ transformation.

\begin{tabular}{llcc}
\hline Peak name & Protein name & Fold Change) & p-value \\
\hline G1T259_RABIT & Family with sequence similarity 71 member & -3.30 & 0.005 \\
G1T923_RABIT & C ATPase H+ transporting accessory protein 2 & -2.30 & 0.000 \\
P00919_RABIT & Carbonic anhydrase 2 & -2.12 & 0.047 \\
G1U4K9_RABIT & Uncharacterized protein & -1.96 & 0.038 \\
G1TE39_RABIT & UDP-glucose glycoprotein & -1.59 & 0.007 \\
G1SVH9_RABIT & KIAcosyltransferase 2 & -1.54 & 0.049 \\
G1SUM6_RABIT & Uncharacterized protein & 1.65 & 0.000 \\
B8K131_RABIT & Zeta globin (Predicted) & 1.67 & 0.008 \\
G1TBJ6_RABIT & Pro-epidermal growth factor & 1.88 & 0.030 \\
U3KPB9_RABIT & Uncharacterized protein & 1.97 & 0.029 \\
U3KNX0_RABIT & Uncharacterized protein & 3.26 & 0.009 \\
G1T0A6_RABIT & Chromosome 16 open reading frame 89 & 3.62 & 0.002 \\
U3KNB5_RABIT & Lipocln_cytosolic_FA-bd_dom domain- & 4.47 & 0.000 \\
\hline & containing protein & &
\end{tabular}


Table 4. Reproductive performance of inseminated does (least square mean \pm standard error least).

\begin{tabular}{ccccc}
\hline Male group & $\mathbf{N}^{\mathbf{0}}$ Does & Kindling rate & Total litter size & Alive born \\
\hline G21V & 159 & $0.73 \pm 0.036$ & $11.3 \pm 0.35$ & $10.5 \pm 0.37$ \\
G39V & 152 & $0.69 \pm 0.038$ & $12.3 \pm 0.37$ & $10.9 \pm 0.40$ \\
Total & 311 & $0.71 \pm 0.026$ & $11.8 \pm 0.25$ & $10.7 \pm 0.27$ \\
\hline
\end{tabular}


Figure 1. Flowchart of the experiment performed to obtain the evaluated generations of a rabbit line selected by growth rate.

Figure 2a. Partial Least Squares Discriminant Analysis (PLS-DA) showing the classification of seminal plasma samples belonging to G21V and G39V.

Figure 2b. Partial Least Squares Discriminant Analysis (PLS-DA) showing the classification of sperm samples belonging to G21V and G39V.

Figure 3a. Heat map representing levels of differentially expressed seminal plasma proteins between male groups (G21V and G39V).

Figure $3 b$. Heat map representing levels of differentially expressed sperm proteins between male groups (G21V and G39V).

Figure 4a. Distribution of molecular function, biological process and cell components of differentially expressed seminal plasma proteins between male groups (G21V and G39V).

Figure $4 \mathrm{~b}$. Distribution of molecular function, biological process and cell components of differentially expressed sperm proteins between male groups (G21V and G39V). 
Supplementary:

Table 1. List of differentially expressed proteins in rabbit seminal plasma (A) between male groups (G21V and G39V).

\begin{tabular}{|c|c|c|c|c|}
\hline $\begin{array}{l}\text { Peak } \\
\text { name }\end{array}$ & Protein name & Gene name & $\begin{array}{c}\text { Log2 } \\
\text { (Fold } \\
\text { Change) }\end{array}$ & p-value \\
\hline G1TIY2 & Uncharacterized protein & & -3.960 & 0.004 \\
\hline G1SKP2 & Importin 5 & IPO5 & -2.908 & 0.046 \\
\hline G1SQG6 & Serpin family A member 5 & SERPINA5 & -2.352 & 0.004 \\
\hline P02779 & Uteroglobin & SCGB1A1 & -2.246 & 0.003 \\
\hline G1T4H3 & $\begin{array}{l}\text { Protein disulfide isomerase family A member } \\
6\end{array}$ & PDIA6 & -2.150 & 0.049 \\
\hline W5PGW8 & X-prolyl aminopeptidase 1 & XPNPEP1 & -2.138 & 0.048 \\
\hline G1SPY1 & 1,4-alpha-glucan branching enzyme 1 & GBE1 & -2.027 & 0.027 \\
\hline W5PW05 & Malate dehydrogenase 2 & $\mathrm{MDH} 2$ & -1.774 & 0.014 \\
\hline W5PYV2 & IZUMO family member 4 & IZUMO4 & -1.700 & 0.004 \\
\hline G1U8K1 & Uncharacterized protein & $\begin{array}{l}\text { LOC } 1003466 \\
90\end{array}$ & -1.699 & 0.029 \\
\hline $\begin{array}{l}\text { A0A0D9 } \\
\text { RUT7 }\end{array}$ & WD repeat domain 1 & WDR1 & -1.658 & 0.023 \\
\hline P00919 & Carbonic anhydrase 2 & CA2 & -1.634 & 0.044 \\
\hline S9XG46 & Tubulin alpha chain (Fragment) & $\begin{array}{c}\text { CB1_0003020 } \\
01\end{array}$ & -1.599 & 0.050 \\
\hline G1SNK5 & Uncharacterized protein & GGCT & -1.552 & 0.019 \\
\hline G1T763 & Polymeric immunoglobuli & PIGR & -1.474 & 0.031 \\
\hline G1TI27 & $\begin{array}{l}\text { Solute carrier family } 2 \text {, facilitated glucose } \\
\text { transporter member } 3\end{array}$ & SLC2A3 & -1.445 & 0.042 \\
\hline G1TUC8 & Actinin alpha 4 & ACTN4 & -1.415 & 0.025 \\
\hline G1T8S8 & Alpha-mannosidase & $\begin{array}{l}\text { LOC } 1003467 \\
72\end{array}$ & -1.369 & 0.028 \\
\hline U3BZ94 & Tubulin beta chain & TUBB4B & -1.362 & 0.027 \\
\hline G1T5D5 & Dipeptidase & DPEP2 & -1.334 & 0.017 \\
\hline U3FJP7 & $\begin{array}{l}\text { Serine/threonine-protein phosphatase } 2 \mathrm{~A} 65 \\
\mathrm{kDa} \text { regulatory subunit A alpha isoform }\end{array}$ & PPP2R1A & -1.317 & 0.041 \\
\hline L5L7E3 & Inositol-3-phosphate synthase 1 & $\begin{array}{l}\text { PAL_GLEAN } \\
10006691\end{array}$ & -1.315 & 0.044 \\
\hline W5Q7U7 & Serine/threonine-protein phosphatase & PPP1CC & -1.188 & 0.049 \\
\hline G1SS49 & $\begin{array}{l}\text { Haloacid dehalogenase like hydrolase } \\
\text { domain-containing } 2\end{array}$ & HDHD2 & -1.177 & 0.042 \\
\hline M3XT75 & Interleukin 4 induced 1 & IL4I1 & -1.160 & 0.024 \\
\hline G1SXQ0 & Glutathione S-transferase & GSTM3 & -1.151 & 0.037 \\
\hline M3WG29 & Thyroglobulin & TG & -1.105 & 0.002 \\
\hline U3CJL4 & Ropporin-1B & ROPN1B & -1.089 & 0.038 \\
\hline S7N & Eukaryotic initiation factor 4A-II & D623_100161 & -1.081 & 0.049 \\
\hline M3YVB2 & Carboxypeptidase & SCPEP1 & -1.075 & 0.027 \\
\hline G3RBN0 & Desmoplakin & DSP & -1.043 & 0.044 \\
\hline G1TA48 & EH-domain containing 4 & EHD4 & -1.038 & 0.049 \\
\hline
\end{tabular}


G1SP77 Solute carrier family 44 member 5

B6V9S8 Chaperonin-containing T-complex

polypeptide eta subunit

G1SDH3 Prolylcarboxypeptidase

G1T0H5 LDL receptor related protein 2

G1U0R8 Uncharacterized protein

A0A2I3H Capping actin protein of muscle Z-line alpha

718 subunit 1

G1TLQ2 Uncharacterized protein

U6CPY0 Glutaredoxin-1

G1U522 Protein kinase cAMP-dependent type II regulatory subunit alpha

U3FVV8 T-complex protein 1 subunit beta isoform 1

W5Q805 Proteasome 26S subunit, ATPase 6

U3F8X4 Clathrin heavy chain

W5Q2N2 Proteasome 26S subunit, non-ATPase 12

G1SK80 Zona pellucida binding protein

Q9TTC6 Peptidyl-prolyl cis-trans isomerase A

W5NPN4

Heat shock protein family A (Hsp70) member 8

G1U723 3alpha/17beta/20alpha-hydroxysteroid dehydrogenase

G1T678 Uncharacterized protein

G1SKA8 Acrosin binding protein

W5P0A6 Platelet activating factor acetyl hydrolase 1b catalytic subunit 2

G5AZH1 5'-nucleotidase

G1TB50 Syndecan binding protein

S7N9H1 Alpha-aminoadipic semialdehyde

dehydrogenase

V9HW12 Epididymis secretory sperm binding protein $\mathrm{Li} 2 \mathrm{a}$

P46409 Glutathione S-transferase Mu 1

G1SCT4 Uncharacterized protein

W5PY41 OTU deubiquitinase, ubiquitin aldehyde

binding 2

G1TMY8 Uncharacterized protein

F7HBU3 Chondroadherin

G1T0A6 Chromosome 16 open reading frame 89

U3KNX0 Uncharacterized protein

A0A1U7

Q3W6
Author version of the manuscript

$\begin{array}{lll}\text { SLC44A5 } & -0.997 & 0.025\end{array}$

$\begin{array}{ll}-0.985 & 0.042\end{array}$

$\begin{array}{lll}\text { PRCP } & -0.969 & 0.008\end{array}$

$\begin{array}{lll}\text { LRP2 } & -0.936 & 0.044\end{array}$

$-0.919 \quad 0.046$

$\begin{array}{lll}\text { CAPZA1 } & -0.911 & 0.017\end{array}$

$\begin{array}{ll}-0.884 & 0.025\end{array}$

$\begin{array}{lll}\text { GLRX1 } & -0.880 \quad 0.015\end{array}$

$\begin{array}{lll}\text { PRKAR2A } & -0.838 \quad 0.030\end{array}$

$\begin{array}{lll}\text { CCT2 } & -0.834 & 0.032\end{array}$

$\begin{array}{lll}\text { PSMC6 } & -0.814 & 0.034\end{array}$

$\begin{array}{lll}\text { CLTC } & -0.814 & 0.033\end{array}$

$\begin{array}{lll}\text { PSMD12 } & -0.775 & 0.017\end{array}$

$\begin{array}{lll}\text { ZPBP } & -0.752 & 0.046\end{array}$

$\begin{array}{lll}\text { PPIA } & -0.704 & 0.043\end{array}$

$\begin{array}{lll}\text { HSPA8 } & -0.701 \quad 0.010\end{array}$

$\begin{array}{lll}\text { PGER5 } & -0.693 \quad 0.034\end{array}$

$\begin{array}{lll}\text { ACAT2 } & -0.679 & 0.043\end{array}$

$\begin{array}{lll}\text { ACRBP } & -0.589 & 0.038\end{array}$

$\begin{array}{lll}\text { PAFAH1B2 } & -0.577 & 0.004\end{array}$

$\begin{array}{lll}\text { GW7 } 18824 & -0.577 & 0.043\end{array}$

$\begin{array}{lll}\text { SDCBP } & -0.551 & 0.027\end{array}$

$\begin{array}{ccc}\text { D623_100269 } & -0.482 & 0.018\end{array}$

HEL-S-2a $\quad-0.461 \quad 0.049$

$0.360 \quad 0.037$

$0.751 \quad 0.007$

$\begin{array}{lll}\text { OTUB2 } & 0.853 & 0.009\end{array}$

$\begin{array}{lll}\text { TMPRSS2 } & 1.520 \quad 0.035\end{array}$

$\begin{array}{lll}\text { CHAD } & 1.590 & 0.000\end{array}$

$\begin{array}{lll}\text { C16orf89 } & 2.208 \quad 0.031\end{array}$

$\begin{array}{ccc}\text { LOC } 1003500 & 2.413 & 0.015\end{array}$

$\mathrm{Ca} 2$

2.750

0.011 
Table 2. List of differentially expressed proteins in rabbit sperm between male groups (G21V and G39V).

\begin{tabular}{|c|c|c|c|c|}
\hline Peak name & Protein name & Gene name & $\begin{array}{c}\text { Log2 } \\
\text { (Fold } \\
\text { Change) }\end{array}$ & p-value \\
\hline U3DHN2 & Choline/ethanolamine kinase & CHKB & -4.292 & 0.000 \\
\hline G1T259 & $\begin{array}{l}\text { Family with sequence similarity } 71 \\
\text { member C }\end{array}$ & FAM71C & -3.302 & 0.005 \\
\hline S9XHL9 & Uncharacterized protein & CB1_000231004 & -2.932 & 0.029 \\
\hline A0A1D5QN77 & Uncharacterized protein & & -2.549 & 0.004 \\
\hline G1T923 & $\begin{array}{l}\text { ATPase } \mathrm{H}+\text { transporting accessory } \\
\text { protein } 2\end{array}$ & АТР6АР2 & -2.301 & 0.000 \\
\hline W5Q1D9 & Mitogen-activated protein kinase 4 & MAP2K4 & -2.157 & 0.010 \\
\hline P00919 & Carbonic anhydrase 2 & CA2 & -2.120 & 0.047 \\
\hline G1U4K9 & Uncharacterized protein & LOC 100359206 & -1.959 & 0.038 \\
\hline A0A0D9RHG6 & IZUMO family member 4 & IZUMO4 & -1.914 & 0.006 \\
\hline H0XZT4 & Calicin & $\mathrm{CCIN}$ & -1.889 & 0.001 \\
\hline A0A1U7TH09 & arginine--tRNA ligase. cytoplasmic & RARS & -1.821 & 0.034 \\
\hline G1TE39 & $\begin{array}{l}\text { UDP-glucose glycoprotein } \\
\text { glucosyltransferase } 2\end{array}$ & UGGT2 & -1.587 & 0.007 \\
\hline G1SVH9 & KIAA1324 & KIAA1324 & -1.535 & 0.049 \\
\hline G1T9L3 & Cilia and flagella associated protein 61 & CFAP61 & -1.363 & 0.050 \\
\hline W5P2U9 & Leucine rich repeat containing 59 & LRRC59 & -1.311 & 0.041 \\
\hline $\mathrm{B} 7 \mathrm{NZB} 0$ & $\begin{array}{l}\text { Tryptophan rich basic protein } \\
\text { (Predicted) }\end{array}$ & WRB & -1.272 & 0.030 \\
\hline Q71DI1 & Dermcidin & & -1.254 & 0.041 \\
\hline G1TX59 & $\begin{array}{l}\text { Serine/threonine-protein phosphatase } 2 \mathrm{~A} \\
\text { activator }\end{array}$ & PTPA & -1.234 & 0.014 \\
\hline G1SWT1 & Phosphodiesterase & PDE10A & -1.161 & 0.046 \\
\hline G1SSU3 & Monoglyceride lipase & MGLL & -1.126 & 0.003 \\
\hline G1T7H0 & $\begin{array}{l}\text { Heterogeneous nuclear } \\
\text { ribonucleoprotein } U\end{array}$ & HNRNPU & -1.106 & 0.044 \\
\hline |L8YCZ7 & Oligoribonuclease. mitochondrial & TREES_T100015334 & $-1,099$ & 0.026 \\
\hline G1SQ27 & Clusterin & CLU & -1.098 & 0.013 \\
\hline G1TZ19 & $\begin{array}{l}\text { Diablo IAP-binding mitochondrial } \\
\text { protein }\end{array}$ & DIABLO & -1.077 & 0.049 \\
\hline Q3TX38 & Uncharacterized protein & Vdac3 & -1.036 & 0.012 \\
\hline Q53ZP9 & Heat shock protein apg-1 & & -1.027 & 0.002 \\
\hline I3LYQ8 & Radial spoke head 6 homolog A & RSPH6A & -1.019 & 0.047 \\
\hline A0A1S3A5Y3 & $\begin{array}{l}\text { 26S proteasome non-ATPase regulatory } \\
\text { subunit } 2\end{array}$ & PSMD2 & -1.016 & 0.031 \\
\hline G1SPR9 & Ribophorin II & RPN2 & -1.015 & 0.030 \\
\hline L9L3I2 & Uncharacterized protein & TREES_T100009695 & -0.971 & 0.028 \\
\hline G1SUK4 & Mannose-6-phosphate isomerase & MPI & -0.963 & 0.041 \\
\hline G1SY44 & Dpy-19 like 2 & DPY19L2 & -0.960 & 0.009 \\
\hline B6RFK9 & Calcium-transporting ATPase & & -0.954 & 0.047 \\
\hline P15253 & Calreticulin & CALR & -0.941 & 0.037 \\
\hline Q3UJN2 & RuvB-like helicase & Ruvbl1 & -0.938 & 0.010 \\
\hline
\end{tabular}




\begin{tabular}{|c|c|c|c|c|}
\hline \multirow[b]{2}{*}{ W5PG36 } & & \multicolumn{3}{|c|}{ Author version of the manuscript } \\
\hline & & VDAC2 & -0.919 & 0.034 \\
\hline Т0MHC0 & $\begin{array}{l}\text { Dolichyl-diphosphooligosaccharide-- } \\
\text { protein glycosyltransferase } 48 \mathrm{kDa} \\
\text { subunit }\end{array}$ & CB1_001086058 & -0.910 & 0.021 \\
\hline F6UQ19 & ADP-ribosylation factor like GTPase 8B & ARL8B & -0.878 & 0.012 \\
\hline G1T6H7 & Lipase I & LIPI & -0.871 & 0.029 \\
\hline Q8K1X5 & EH-domain containing 1 (Fragment) & Ehd1 & -0.860 & 0.000 \\
\hline G1U9S2 & Serum albumin & ALB & -0.844 & 0.048 \\
\hline H0VL12 & Ubiquitin carboxyl-terminal hydrolase & Uchl3 & -0.819 & 0.042 \\
\hline G1SDD7 & Polyamine oxidase & PAOX & -0.799 & 0.014 \\
\hline M3Y7C5 & $\begin{array}{l}\text { Dolichyl-diphosphooligosaccharide-- } \\
\text { protein glycosyltransferase subunit } \\
\text { DAD1 }\end{array}$ & DAD1 & -0.786 & 0.009 \\
\hline W5Q4H1 & Uncharacterized protein & TMED7 & -0.774 & 0.025 \\
\hline G1SKP2 & Importin 5 & IPO5 & -0.739 & 0.031 \\
\hline S7MLC2 & Ribosomal protein L15 & D623_10020435 & -0.738 & 0.023 \\
\hline W5P4C0 & Uncharacterized protein & RPS13 & -0.726 & 0.007 \\
\hline W5PKQ2 & $\begin{array}{l}\text { Family with sequence similarity } 213 \\
\text { member A }\end{array}$ & FAM213A & -0.717 & 0.022 \\
\hline H9YYT7 & Calnexin & CANX & -0.714 & 0.032 \\
\hline G1SRN0 & Dynein axonemal heavy chain 7 & DNAH7 & -0.694 & 0.031 \\
\hline G1TDX0 & Calpain 11 & CAPN11 & -0.693 & 0.036 \\
\hline G1SVQ0 & Glutathione S-transferase omega 2 & GSTO2 & -0.689 & 0.017 \\
\hline F1RFM8 & Dynein axonemal heavy chain 10 & DNAH10 & -0.681 & 0.045 \\
\hline A0A061I1I7 & Clathrin heavy chain 1-like protein & H671_7g18204 & -0.668 & 0.027 \\
\hline U3E190 & ADP-ribosylation factor 3 & ARF3 & -0.668 & 0.036 \\
\hline G3U7Z4 & A-kinase anchoring protein 4 & AKAP4 & -0.628 & 0.009 \\
\hline W5PAG0 & Lysine--tRNA ligase & KARS & -0.625 & 0.020 \\
\hline U6DJ81 & $\begin{array}{l}\text { 26S proteasome non-ATPase regulatory } \\
\text { subunit } 6 \text { (Fragment) }\end{array}$ & PSMD6 & -0.615 & 0.044 \\
\hline G1T4R5 & $\begin{array}{l}\text { Glycerophosphodiester } \\
\text { phosphodiesterase domain-containing } 1\end{array}$ & GDPD1 & -0.612 & 0.003 \\
\hline W5P1T4 & Serine/threonine-protein phosphatase & PPP4C & -0.610 & 0.037 \\
\hline W5QG71 & Uncharacterized protein & & -0.599 & 0.018 \\
\hline G1TP15 & Proteasome 26S subunit. non-ATPase 3 & PSMD3 & -0.591 & 0.012 \\
\hline A0A091DF21 & $\begin{array}{l}\text { 4-trimethylaminobutyraldehyde } \\
\text { dehydrogenase }\end{array}$ & H920_09468 & -0.584 & 0.020 \\
\hline W5NSP2 & $40 \mathrm{~S}$ ribosomal protein $\mathrm{S} 8$ & RPS8 & -0.581 & 0.049 \\
\hline W5NRL8 & $\begin{array}{l}\text { Eukaryotic translation initiation factor } 3 \\
\text { subunit A }\end{array}$ & EIF3A & -0.573 & 0.004 \\
\hline W6FFT9 & $\begin{array}{l}\text { Signal peptidase complex catalytic } \\
\text { subunit SEC11 }\end{array}$ & SEC11A & -0.570 & 0.049 \\
\hline S9YHZ9 & $60 \mathrm{~S}$ ribosomal protein $\mathrm{L} 7 \mathrm{a}$ & CB1_000282013 & -0.562 & 0.046 \\
\hline G1TZQ6 & $\begin{array}{l}\text { NADH dehydrogenase [ubiquinone] } 1 \\
\text { alpha subcomplex subunit } 10 . \\
\text { mitochondrial }\end{array}$ & NDUFA10 & -0.549 & 0.006 \\
\hline G1TDQ5 & ATP-dependent 6-phosphofructokinase & PFKM & -0.549 & 0.010 \\
\hline W5P0D5 & Proteasome $26 \mathrm{~S}$ subunit. non-ATPase 7 & PSMD7 & -0.548 & 0.007 \\
\hline G1T2I4 & Glutamyl-prolyl-tRNA synthetase & EPRS & -0.547 & 0.003 \\
\hline J9PAN1 & Angiotensin-converting enzyme & LOC100856208 & -0.531 & 0.047 \\
\hline
\end{tabular}




\begin{tabular}{|c|c|c|c|c|}
\hline \multirow[b]{2}{*}{ W5PUU0 } & \multirow[b]{2}{*}{ Uncharacterized protein } & \multicolumn{3}{|c|}{ Author version of the manuscript } \\
\hline & & RPL31 & -0.528 & 0.048 \\
\hline $\mathrm{P} 25227$ & Alpha-1-acid glycoprotein & ORM1 & -0.525 & 0.016 \\
\hline G1SZR0 & Uncharacterized protein & TEX101 & -0.524 & 0.032 \\
\hline W5QG19 & Exportin 1 & XPO1 & -0.518 & 0.032 \\
\hline M3VYE9 & Uncharacterized protein & USMG5 & -0.507 & 0.005 \\
\hline U6CРT9 & Enolase-phosphatase E1 & ENOPH & -0.504 & 0.039 \\
\hline U3KME2 & Proteasome 26S subunit. non-ATPase 13 & PSMD13 & -0.466 & 0.045 \\
\hline G1SR77 & Calcium-transporting ATPase & АТР2B4 & -0.441 & 0.047 \\
\hline Q96G38 & $\begin{array}{l}\text { Eukaryotic translation initiation factor } 3 \\
\text { subunit B (Fragment) }\end{array}$ & EIF3B & -0.433 & 0.009 \\
\hline U3KM71 & Uncharacterized protein & ATP5L & -0.429 & 0.038 \\
\hline G5E8T9 & Hydroxyacyl glutathione hydrolase & Hagh & -0.420 & 0.016 \\
\hline W5QBG6 & Nuclear pore complex protein Nup93 & NUP93 & -0.405 & 0.019 \\
\hline W5PEQ3 & Mindbomb E3 ubiquitin-protein ligase 1 & MIB1 & -0.384 & 0.026 \\
\hline W5P7Z1 & Uncharacterized protein & & -0.351 & 0.038 \\
\hline A0A091DD11 & Kinesin light chain 2 & H920_10239 & $-0,258$ & 0.047 \\
\hline I6YLY8 & Heat shock cognate $71 \mathrm{kDa}$ protein & HSPA8 & 0.339 & 0.026 \\
\hline G1SD34 & $\begin{array}{l}\text { Sodium/potassium-transporting ATPase } \\
\text { subunit beta }\end{array}$ & ATP1B3 & 0.410 & 0.017 \\
\hline G1STX7 & Kynurenine aminotransferase 3 & KYAT3 & 0.450 & 0.016 \\
\hline G1TAY6 & Keratin 19 & KRT19 & 0.507 & 0.032 \\
\hline G1SQ02 & Peroxiredoxin 1 & PRDX1 & 0.523 & 0.045 \\
\hline W5PDG3 & $\begin{array}{l}\text { Glyceraldehyde-3-phosphate } \\
\text { dehydrogenase }\end{array}$ & GAPDH & 0.583 & 0.032 \\
\hline G1SZ00 & Cysteine and glycine rich protein 1 & CSRP1 & 0.670 & 0.048 \\
\hline Q53GD1 & $\begin{array}{l}\text { Guanine nucleotide-binding protein } \\
\text { subunit gamma (Fragment) }\end{array}$ & & 0.679 & 0.041 \\
\hline G1U3K5 & Androglobin & ADGB & 0.722 & 0.027 \\
\hline W5NYF9 & 5'-nucleotidase. cytosolic II & NT5C2 & 0.723 & 0.034 \\
\hline G1TY46 & $\begin{array}{l}\text { Immunoglobulin superfamily containing } \\
\text { leucine rich repeat }\end{array}$ & ISLR & 0.745 & 0.009 \\
\hline S9W5U7 & 60S ribosomal protein L18 & CB1_007371005 & 0.794 & 0.017 \\
\hline G1TYT4 & Angiotensin-converting enzyme & $\mathrm{ACE}$ & 0.818 & 0.009 \\
\hline G1TUC8 & Actinin alpha 4 & ACTN4 & 0.844 & 0.049 \\
\hline G1SYV9 & Talin 1 & TLN1 & 0.853 & 0.012 \\
\hline G1TBX4 & Carboxypeptidase & CPVL & 0.875 & 0.002 \\
\hline G1U4G9 & Chloride intracellular channel protein & CLIC1 & 0.896 & 0.018 \\
\hline M3WPD9 & Alpha-methylacyl-CoA racemase & AMACR & 0.918 & 0.019 \\
\hline A0A1A6HNG5 & Uncharacterized protein & A6R68_22009 & 0.928 & 0.028 \\
\hline W5Q8B1 & Glutathione peroxidase & GPX6 & 0.971 & 0.001 \\
\hline G1T5Q9 & $\begin{array}{l}\text { Bactericidal permeability-increasing } \\
\text { protein }\end{array}$ & BPI & 0.971 & 0.011 \\
\hline G1SYM3 & Tetraspanin & CD9 & 1.001 & 0.030 \\
\hline A0A091DW69 & Beta-1.4-galactosyltransferase 1 & H920_03195 & 1.020 & 0.008 \\
\hline M1ZMP8 & Aldehyde oxidase 3 & & 1.026 & 0.019 \\
\hline G1SLU0 & VPS37B. ESCRT-I subunit & VPS37B & 1.066 & 0.050 \\
\hline G1SD48 & Glucosylceramidase & GBA & 1.130 & 0.004 \\
\hline W5Q9V4 & RAB3D. member RAS oncogene family & RAB3D & 1.155 & 0.020 \\
\hline W5QCT2 & COP9 signalosome subunit 8 & COPS8 & 1.238 & 0.047 \\
\hline
\end{tabular}




\begin{tabular}{|c|c|c|c|c|}
\hline G1SFR5 & $\begin{array}{l}\text { Peptidylglycine alpha-amidating } \\
\text { monooxygenase }\end{array}$ & PAM & 1.298 & 0.005 \\
\hline G1SWH0 & Semaphorin $3 \mathrm{C}$ & SEMA3C & 1.343 & 0.022 \\
\hline G1T6B8 & Lysozyme & LOC100341160 & 1.470 & 0.002 \\
\hline U3BEF5 & $\begin{array}{l}\text { SH3 domain-binding glutamic acid-rich- } \\
\text { like protein }\end{array}$ & SH3BGRL2 & 1.552 & 0.036 \\
\hline G1SUM6 & Uncharacterized protein & $\mathrm{CPE}$ & 1.654 & 0.000 \\
\hline I3NAI1 & Uncharacterized protein & Sept9 & 1.663 & 0.023 \\
\hline B8K131 & Zeta globin (Predicted) & HBZ_1 & 1.666 & 0.008 \\
\hline H2PZD8 & $\begin{array}{l}\text { Transforming growth factor. beta } \\
\text { receptor III }\end{array}$ & TGFBR3 & 1.682 & 0.006 \\
\hline G1TBJ6 & Pro-epidermal growth factor & EGF & 1.878 & 0.030 \\
\hline W5PYX5 & Chromosome 5 open reading frame 49 & C5orf49 & 1.937 & 0.039 \\
\hline U3КРB9 & Uncharacterized protein & & 1.972 & 0.029 \\
\hline F1RT93 & Chondroadherin & CHAD & 2.097 & 0.004 \\
\hline Q5PQN1 & $\begin{array}{l}\text { Probable E3 ubiquitin-protein ligase } \\
\text { HERC4 }\end{array}$ & Herc4 & 2.600 & 0.008 \\
\hline U3KNX0 & Uncharacterized protein & LOC100350057 & 3.263 & 0.009 \\
\hline G1T0A6 & Chromosome 16 open reading frame 89 & C16orf89 & 3.616 & 0.002 \\
\hline U3KNB5 & $\begin{array}{l}\text { Lipocln_cytosolic_FA-bd_dom domain- } \\
\text { containing protein }\end{array}$ & LOC 103347146 & 4.467 & 0.000 \\
\hline
\end{tabular}

